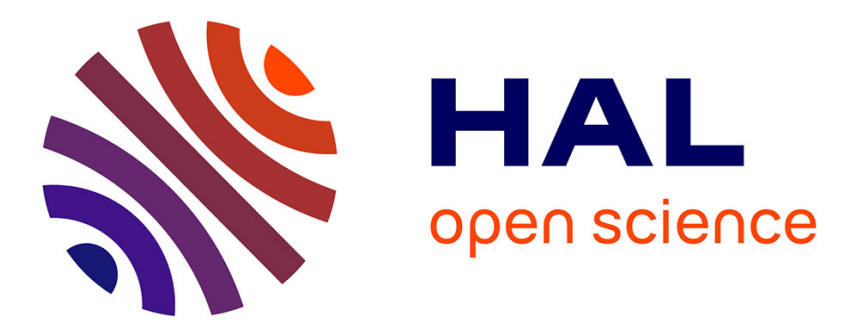

\title{
Cysteine-montmorillonite composites for heavy metal cation complexation: A combined experimental and theoretical study
}

Khaled El Adraa, Thomas Georgelin, Jean-François Lambert, Farouk Jaber, Frederik Tielens, Maguy Jaber

\section{To cite this version:}

Khaled El Adraa, Thomas Georgelin, Jean-François Lambert, Farouk Jaber, Frederik Tielens, et al.. Cysteine-montmorillonite composites for heavy metal cation complexation: A combined experimental and theoretical study. Chemical Engineering Journal, 2017, 314, pp.406 - 417. 10.1016/j.cej.2016.11.160 . hal-01490419

\section{HAL Id: hal-01490419 \\ https://hal.sorbonne-universite.fr/hal-01490419}

Submitted on 15 Mar 2017

HAL is a multi-disciplinary open access archive for the deposit and dissemination of scientific research documents, whether they are published or not. The documents may come from teaching and research institutions in France or abroad, or from public or private research centers.
L'archive ouverte pluridisciplinaire HAL, est destinée au dépôt et à la diffusion de documents scientifiques de niveau recherche, publiés ou non, émanant des établissements d'enseignement et de recherche français ou étrangers, des laboratoires publics ou privés. 


\section{Cysteine-Montmorillonite Composites for Heavy Metal}

\section{Cation Complexation: a Combined Experimental and}

\section{Theoretical Study}

Khaled El Adraa ${ }^{1}$, Thomas Georgelin ${ }^{2}$, Jean-François Lambert ${ }^{2}$, Farouk Jaber $^{3}$, Frederik Tielens ${ }^{4}$, Maguy Jaber ${ }^{1 *}$

${ }^{1}$ Sorbonne Universités, UPMC Paris06, UMR 8220, Laboratoire d'Archéologie Moléculaire et Structurale, 4 place Jussieu , F-75005 Paris, France

${ }^{2}$ Sorbonne Universités, UPMC Paris 06, UMR7179, Laboratoire de Réactivité de Surface, 4 place Jussieu, F-75005 Paris, France

${ }^{3}$ Laboratoire d'Analyse des Composés Organiques (509), Univ. Libanaise - Campus Universitaire de Rafic HARIRI, Faculté des Sciences I. Dép. de Chimie et de Biochimie, Laboratoire d'Analyse de Pesticides et de Polluants Organiques, Commission Libanaise de l'Energie Atomique, B. P. 11- 8281, Riad El Solh, 11072260 Beyrouth, Liban

${ }^{4}$ Sorbonne Universités, UPMC Univ Paris06, UMR 7574, Laboratoire Chimie de la Matière Condensée, Collège de France, 11 place Marcelin Berthelot, 75231 Paris Cedex 05, France

\footnotetext{
* Authors to whom correspondence should be sent: maguy.jaber@upmc.fr; frederik.tielens@upmc.fr
} 


\section{TOC}

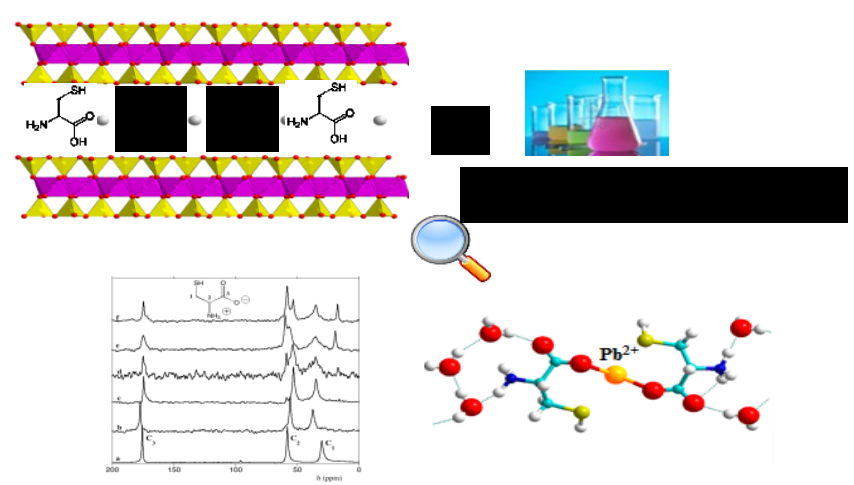

Keywords: Montmorillonite, heavy metal cations, Cysteine, DFT, NMR 


\begin{abstract}
Green Composites based on montmorillonite (Mt) and cysteine, were prepared for heavy metal removal. A comparison between the adsorption properties of the resulting hybrid inorganic-organic materials and the pure montmorillonite was carried out for the following heavy metal cations $\mathrm{Cd}^{2+}, \mathrm{Hg}^{2+}, \mathrm{Pb}^{2+}, \mathrm{Co}^{2+}$ and $\mathrm{Zn}^{2+}$. It appears that the adsorption capacity is higher on the composite. Moreover, in release experiments, the heavy metal cations are more strongly retained by the hybrid material. Interactions between the hybrid clay mineral and the inorganic hosts were studied by spectroscopic methods such as solid-state NMR (Nuclear Magnetic Resonance) and FTIR (Fourier Transform Infrared). The experimental data were in agreement with the theoretical periodic DFT (Density Functional Theory) calculations where a molecular picture of the adsorption complex is proposed.
\end{abstract}

Keywords: Montmorillonite, heavy metal cations, Cysteine, DFT, NMR

*Maguy Jaber : maguy.jaber@upmc.fr 


\section{INTRODUCTION}

Nowadays, the contamination of soils and water with heavy metal cations leads to important environmental concerns.[1-3] The presence of these contaminants is mainly due to industrial activities. While extensive studies have been devoted to the remediation in water through the use of plants [4-6] or minerals as adsorbants (apatite, iron oxides nanoparticles...)[7-11], the depollution of soils requires other considerations. In the context of soil remediation, trace elements cannot be destroyed like organic contaminants but only be relocated from one place to another. Indeed, the presence of nutriments and inorganic salts essential for the ecosystem are often co-adsorbed with the heavy metal cations. Therefore, it is important to develop new selective platforms capable to hinder the spread of contaminants in soil.

Clay minerals are one major component of soils and sediments. Due to their natural abundance, they are inexpensive and biocompatible. In addition, their chemical and mechanical stability, high surface area, cationic exchange capacity and structural properties make them good candidates for applications in many fields including remediation. Clay minerals are easily functionalized, making them a modular material. Several works have been reported on the use of clay minerals as a potential platform for heavy metal retention [12-21]. From these studies, it appears that the adsorption of heavy metal cations on clay minerals strongly depends on the $\mathrm{pH}$ of the media and becomes much less effective in acidic solutions. The interaction is usually described in terms of two basic mechanisms: (a) cation exchange in the interlayers [22], (b) inner-sphere complexation with $-\mathrm{OH}$ groups at the edges and/or at the surfaces of the clay mineral. 
In spite of the huge amounts of papers reporting the use of untreated clay minerals for the heavy metal retention, the cation exchange capacity is not enough for large-scale applications and seems restricted to model system remediation. In order to increase the selectivity and the adsorption capacity for heavy metal cations, the immobilization of chelating agents on clay minerals has been widely studied. Vermiculite modified by different acids such as lactic acid, tartric acid, citric acid and malonic acid have been used for the chelation of different metal ions such as $\mathrm{Pb}^{2+}, \mathrm{Cd}^{2+}, \mathrm{Ni}^{2+}$ and $\mathrm{Zn}^{2+}[23,24]$. Singh et al. [25] reported the immobilization of citrate and glycine as chelating agents on kaolinite and their ability to complex $\mathrm{Hg}^{2+}$. Two major functional groups have been found to be responsible for the binding of $\mathrm{Hg}^{2+}$ to kaolinite, i.e., carboxylic group (O-ligand) and amine group (N-ligand).

The use of amino acids as additives is suggested by their binding of heavy metals in soils. The interactions between these biomolecules and various inorganic matrices including clay minerals have already been reported [26-35].

One amino acid, L-cysteine, appears particularly interesting for remediation processes. Due to its $\beta$-thiol group in combination with the carboxylate and amino groups, L-cysteine has the highest affinity to soft (according to Pearson's definition) metal ions[36]. The adsorption of cysteine on bentonite and montmorillonite was investigated and different parameters were studied including temperature, $\mathrm{pH}$ and contact time. The amount of adsorbed cysteine was $\mathrm{pH}$ dependent[37] and the quantity of $\mathrm{Cd}^{2+}$ retained was found to be $20 \%$ higher on the composite than on raw bentonite. On beidellite and montmorillonite, $\mathrm{Cu}$-cysteine complexes were more retained in the interlayer space than Cu-glycine[38]. Different papers[39, 40] have reported on the chelation effect of metal ions with cysteine intercalated in the interlayer space of montmorillonite. The thermal stability of these resulting complexes with $\mathrm{Hg}^{2+}$ was the highest 
on cysteine vermiculite and montmorillonite composite. Kaolinite was also tested with cysteine and a 1:1 complex was observed with $\mathrm{Cd}^{2+}$.

All the reported works until now described the adsorption capacity of the clay minerals toward heavy metal cations. While various characterization techniques were employed on the cations-clay mineral solids, the use of a combined theoretical and experimental approach is now state-of-the-art.

Cysteine interaction with cations has been studied in the gas phase at DFT level[41], and the modeling of clay-cation-water systems, especially montmorillonite systems have been studied using a molecular description of the solvent and clay sheet $[42,43]$. Earlier we have investigated L-DOPA and other amino acids intercalation in Saponite[44].

The purpose of the present work is to investigate at the molecular level, the capacity of cysteine-montmorillonite composites to chelate several heavy metal cations namely $\mathrm{Hg}^{2+}, \mathrm{Zn}^{2+}$, $\mathrm{Co}^{2+}, \mathrm{Cd}^{2+}, \mathrm{Pb}^{2+}$, and $\mathrm{Cu}^{2+}$, employing combined experimental and theoretical approaches. Experimentally, the use of ${ }^{13} \mathrm{C}$ solid state $\mathrm{NMR}$ spectroscopy has allowed to define the interactions between the metal ions and the organic molecule, an aspect which has not been deeply studied yet in the literature. The reversibility of the adsorption (the cations release) has also been investigated. The importance of theoretical chemistry for intercalated materials is crucial since it confirms the experimental data.

\section{EXPERIMENTAL PART}

\subsection{Characterization}

X-Ray powder diffraction (XRD) was carried out with a Bruker D8 Avance diffractometer using the $\mathrm{Cu} \mathrm{K}_{\mathrm{a}}$ radiation (wavelength $1=1.5404 \AA$ ). XRD patterns were recorded between 3 and $70^{\circ}$ with a step size of $0.05^{\circ}$. Thermogravimetric analysis (TGA) of the samples 
was performed on a TA Instruments - Waters LLC, SDT Q600 analyzer with a heating rate of 5 ${ }^{\circ} \mathrm{C} \min ^{-1}$ under dry air flow $\left(100 \mathrm{~mL} \mathrm{~min}^{-1}\right)$. Transmission Electron Microscopy (TEM) measurements of the samples were performed on a JEOL100CX microscope. Samples in the form of bulk powders were suspended in ethanol and then deposited on specific grids (400 mesh copper grids covered with an ultrathin carbon membrane of 2-3 nm thickness).

$\mathrm{N}_{2}$ adsorption isotherms were recorded on a Micromeritis ASAP 2010 gas analyzer. Specific surface areas and pore volumes characteristics of materials were determined by the BET and $\mathrm{BJH}$ models from nitrogen adsorption/desorption experiments carried out at $77 \mathrm{~K}$ on samples outgassed at $250{ }^{\circ} \mathrm{C}$ for $4 \mathrm{~h}$ prior to analysis.

UV absorption spectra have been recorded by using a double-beam Varian Cary 500 UVVis spectrophotometer in the $400-1000 \mathrm{~nm}$ spectral range.

IR of solid samples was recorded in the transmission mode on self-supported pellets in a cell fitted with $\mathrm{KBr}$ windows. Samples may have two positions in the cell, in the oven, allowing in situ thermal treatments under vacuum or various atmospheres, and roomtemperature recording of spectra without reexposure to air. FT-IR spectra were recorded on a Bruker-Vector 22 FT-IR spectrometer equipped with a DTGS detector, having a nominal resolution of $4 \mathrm{~cm}^{-1}$, by adding 128 scans.

Transmission-mode IR spectra were recorded in $\mathrm{KBr}$ pellets on a Bruker Vector 22 with a DTGS detector and a resolution of $4 \mathrm{~cm}^{-1}$.

${ }^{13} \mathrm{C}$ MAS-NMR spectra were obtained on a Bruker Advance 300 spectrometer operating at $\omega_{L}=300 \mathrm{MHz}\left({ }^{1} \mathrm{H}\right)$ and $60.37 \mathrm{MHz}\left({ }^{13} \mathrm{C}\right)$. Proton cross-polarization (CP-MAS) was applied with a contact time of $1 \mathrm{~ms}$. Samples were spun at the magic angle at a frequency of $10 \mathrm{kHz}$. The ${ }^{13} \mathrm{C}$ pulse length was $5 \mathrm{~ms}$ (close to $\pi / 2$ ) and the recycle delay was $5 \mathrm{~s}$. 


\subsection{Experimental procedure}

2.2.1. Material. Montmorillonite powder was prepared according to the procedure of Reinholdt et al. [45]. The molecular formula per half unit cell is $\mathrm{Na}_{0.2}\left[\left(\mathrm{Al}_{1.8} \mathrm{Mg}_{0.2}\right) \mathrm{Si}_{4} \mathrm{O}_{10}(\mathrm{OH})_{2}\right]$, corresponding to a cation exchange capacity (CEC) of 52.77 meq/100g. Cysteine (97\% purity) was purchased from Sigma-Aldrich. The cations of the heavy metals were introduced as chloride salts (99\% purity, sigma Aldrich).

2.2.2. Preparation of cysteine montmorillonite composites. $1 \mathrm{~g}$ of montmorillonite was added to $100 \mathrm{ml}$ of cysteine solution $(10-1 \mathrm{M})$ at natural $\mathrm{pH}(4.4)$. The suspensions were stirred at a constant rate at room temperature. The adsorption kinetics was followed in a preliminary experiment Thus, the adsorption was allowed to reach this apparent equilibrium, and then the tubes were centrifuged at $9000 \mathrm{rpm}$ for $15 \mathrm{~min}$. The products were dried in an oven at $70^{\circ} \mathrm{C}$.

2.2.3. Adsorption of metal ions on Mt and Cys-Mt composites. For adsorption experiments, $0.5 \mathrm{~g}$ of montmorillonite (Mt; this amount contains $0.26 \mathrm{meq}$ of exchangeable cations) or cysteine-montmorillonite composite (Cys-Mt) was added to $50 \mathrm{ml}$ of a $10^{-2} \mathrm{~mol}^{-1} \mathrm{l}^{-1}$ heavy metals solution (i.e. 1 meq of positive charge) at natural $\mathrm{pH}(4.4)$. Thus, the heavy metal cations represented an equivalent fraction of the equivalent fraction charge that amounted to $79.3 \%$. The suspensions were stirred at a constant rate at room temperature. After 24 hours, the suspensions were centrifuged at $9000 \mathrm{rpm}$ for $15 \mathrm{~min}$. The product was dried in an oven at 70 ${ }^{\circ} \mathrm{C}$. The amount of adsorbed heavy metals was analyzed by X-Ray fluorescence.

The desorption of heavy metal cations from heavy metals-Cys-Mt systems was evaluated as follows: $1 \mathrm{~g}$ of the system to be tested was dispersed in $100 \mathrm{~mL}$ of a $0.01 \mathrm{M}$ solution 
of either $\mathrm{NaCl}$ or $\mathrm{SrCl}_{2}$; after $24 \mathrm{~h}$ under stirring, the solid was separated by centrifugation, oven-dried and its elemental analysis was carried out by XRF. The remaining amount of heavy metal was expressed as a percentage of the initial loading.

\section{Computational details}

\subsection{DFT geometrical configurations and molecular dynamics calculations.}

All calculations were performed using the $a b$ initio plane-wave pseudopotential approach as implemented in the VASP code $[46,47]$. The model is presented in Figure 1 (details on DFT calculation are presented in supplementary data). DFT geometrical configurations and molecular dynamics calculations.

The Perdew-Burke-Ernzerhof (PBE) functional $[48,49]$ was chosen to perform the periodic DFT calculations; the accuracy on the overall convergence was tested elsewhere [50].

The valence electrons were treated explicitly and their interactions with the ionic cores are described by the Projector Augmented-Wave method (PAW), $[23,51]$ which allows to use a low energy cutoff equal to $400 \mathrm{eV}$ for the plane-wave basis. The integration over the Brillouin zone was performed on the $\Gamma$-point, in all calculations.

The potential energy surfaces (PES) were systematically explored by ab initio molecular dynamics at $300 \mathrm{~K}$, starting from several configurations. The time step was set at $1.5 \mathrm{fs}$; several starting conformations were considered (but no statistic was performed on the starting conformations) and the run was stopped when an average stable conformation was reached during 500 fs or more; we used a micro-canonical ensemble in the NVT (constant number of molecules, constant volume and constant temperature) approach. To avoid fluctuations due to the large time step chosen, the mass of the hydrogen atom was set to 3 . The local minima found 
in the PES were then optimized at $0 \mathrm{~K}$. It is noticeable that this MD approach allowed us to find the minima of the PES showed in the present paper, which were not intuited beforehand.

In the geometry optimizations at $0 \mathrm{~K}$, the positions of all atoms in the supercell are relaxed in the potential energy determined by the full quantum mechanical electronic structure until the total energy differences between the loops is less than $10^{-4} \mathrm{eV}$.

\subsection{The heavy metals/montmorillonite/cysteine model.}

The montmorillonite material model is built starting from the neutron diffraction data of Gournis et al. [52] Montmorillonite clay has a molar weight per (dry) unit cell of 725.73 to $751.40 \mathrm{~g} / \mathrm{mol}$ corresponding to the general formula:

$$
\mathrm{Na}_{\mathrm{x}}\left[\left(\mathrm{Al}_{2-\mathrm{x}} \mathrm{Mg}_{\mathrm{x}}\right) \mathrm{Si}_{4} \mathrm{O}_{10}(\mathrm{OH})_{2}\right] \text {, where } x=0.2 \text { to } 1.2 \text {. }
$$

The synthetic montmorillonite used in our experiments has $x=0.2$, but the degree of substitution in the model cannot be varied continuously due to the finite number of atoms in the unit cell. Therefore, the formula of bulk Na-montmorillonite half unit cell used in our model is the following:

$$
\mathrm{Na}_{0.17} \mathrm{Al}_{1.83} \mathrm{Mg}_{0.17} \mathrm{Si}_{4} \mathrm{O}_{10}(\mathrm{OH})_{2}
$$

In other words $\mathrm{x}$ is set equal to 0.17 , slightly underestimating the $\mathrm{Al}$ and $\mathrm{Na}$ content, This value can be modeled easily as it corresponds to an integer number of substitutions in six unit cells (one $\mathrm{Mg}$, and therefore one $\mathrm{Na}$ ). Therefore, the number of atoms and geometric size remain reasonable.

Thus, the model consists in a $(3 \times 2 \times 1)$ supercell see Figure 1 , with the following general formula:

$$
\mathrm{NaAl}_{23} \mathrm{Mg} \mathrm{Si}_{48} \mathrm{O}_{120}(\mathrm{OH})_{24}
$$


The different exchangeable cations $\left(\mathrm{Na}^{+}, \mathrm{Hg}^{2+}, \mathrm{Zn}^{2+}, \mathrm{Co}^{2+}, \mathrm{Cd}^{2+}, \mathrm{Pb}^{2+}\right.$, and $\left.\mathrm{Cu}^{2+}\right)$ together with the desired amount of water molecules were introduced in the model and short MD runs were generated to obtain realistic interatomic distances and select starting geometries in order to perform full geometry optimizations. This strategy allowed obtaining the different hydrated clay materials which were later used to investigate the cysteine heavy metal montmorillonite systems.

To obtain a realistic model of a clay mineral in contact with an aqueous solution, a certain number of water molecules must be introduced in the interlayer. For each tested system, we selected the integer number that was closest to the experimentally determined water content, expressed per six unit cells.

Once the Mt model is built, the interlayer space is expanded to introduce the water molecules and cysteine, in accordance with the experimentally observed conditions. It must be underlined that the clay model is a three dimensional repeating unit cell and not a single slab (surface) clay model, using periodic boundary conditions according.

In summary, the cysteine-montmorillonite model is constituted of 8 different atomic species: $\mathrm{H}, \mathrm{C}, \mathrm{N}, \mathrm{O}, \mathrm{Na}, \mathrm{Mg}, \mathrm{Al}, \mathrm{Si}$ and contains about 240 atoms, the exact figure depending on the number of water molecules considered.

The interaction energy per Cysteine molecule was calculated as follows:

$$
\Delta E_{\text {int }}=\left[E\left(\mathrm{Mt}, \text { cation, 2.Cyst, }(\mathrm{n}-4) \cdot \mathrm{H}_{2} \mathrm{O}\right)-E\left(\mathrm{Mt}, \text { cation,n. } \mathrm{H}_{2} \mathrm{O}\right)-2 \cdot E(\mathrm{Cyst})-4 \cdot E\left(\mathrm{H}_{2} \mathrm{O}\right)\right] / 2(4)
$$

With $E\left(\right.$ Mt,cation,2.Cyst,(n-4). $\left.\mathrm{H}_{2} \mathrm{O}\right)$ the total energy of the Cysteine loaded hydrated Mt, $E\left(\mathrm{Mt}\right.$, cation, $\left.\mathrm{n} . \mathrm{H}_{2} \mathrm{O}\right)$ the total energy of the hydrated Mt, E(Cyst) the total energy of one cysteine molecule in vacuum, and $E\left(\mathrm{H}_{2} \mathrm{O}\right)$ the energy of one molecule of water in vacuum. In 
this equation it is supposed that 2 water molecules replaced 1 Cysteine molecule in the $\mathrm{Mt}$ interlayer. The number of water molecules (n) present in the Mt interlayer was optimized, by calculating a series of values ( \pm 2 water molecules calculated from the TGA data), and the most energetically favorable one was retained.

One should notice that theoretical results concern only the intercalated layers. The relative proportion of intercalated vs. unintercalated layers cannot be addressed due to the small scale of the supercell.

\section{Results and discussion}

\subsection{Raw montmorillonite and Cys-Mt.}

The XRD pattern of the as-synthesized montmorillonite exhibits hkl bands at $4.45-4.48 \AA$ $(020,110), 2.52-2.58 \AA(130,200)$ and $1.67-1.70 \AA(210)$, which are typical of smectites (Figure 2).[53] The (001) reflexion shows an inter-reticular distance of $1.23 \mathrm{~nm}$, corresponding to the "one-water layer" form. After cysteine adsorption, the $\mathrm{d}_{001}$ increases to $1.49 \mathrm{~nm}$ indicating that at least part of the cysteine molecules is intercalated in the interlayer space of the montmorillonite (Table 1).

The interlayer spacing, about $0.53 \mathrm{~nm}$, is higher than the value expected for a cysteine molecule lying flat in the interlayer $(0.32 \mathrm{~nm})$. On the basis of standard covalent radius and bond length values, it seems to correspond more closely to the form shown in the right part of Figure 3. 
Thermogravimetric curves are presented in Figure 4 and Figure 5. With respect to the initial montmorillonite, the DTG curve of the Na-Cys-Montmorillonite composite shows an additional, sharp exothermic phenomenon in the $200-300{ }^{\circ} \mathrm{C}$ domain, which is obviously correlated with an oxidative degradation of the amino acid; a simple desorption would yield an endothermic peak. The integration of this peak yields a value of $4.3 \%$ of the dry matter. The total weight loss excess in the $200-800{ }^{\circ} \mathrm{C}$ range amounts to $6.98 \%$ of the montmorillonite dry weight, and we believe that this constitutes a good estimate of the cysteine content. This would correspond to 0.43 molecules per unit cell, which is certainly not excessive. Indeed, taking into account the available surface of the interlayer space $\left(45 \times 10^{-2} \mathrm{~nm}^{2}, a \times b\right)$ and the surface that a cysteine chain $\left(28 \times 10^{-2} \mathrm{~nm}^{2}\right.$ calculated by assimilating the organic matter to a cylinder; $l \times L, l$, and $L$ were determined taking into account the $\mathrm{C}-\mathrm{H}, \mathrm{Si}-\mathrm{C}$ and $\mathrm{S}-\mathrm{H}$ bounds) occupies, the interlayer space could contain 1.5 organic chains per unit cell (Table 2).

The treatment with cysteine also produces a slight decrease in water content, due to the fact that cysteine displaces water molecules in the interlayer. Another reason is the lower affinity for water of many organic molecules, such as cysteine, when compared to inorganic cations.

\subsection{Heavy metal-montmorillonite.}

The adsorption of heavy metal cations by cationic exchange induces a slight decrease in the $\mathrm{d}_{001}$ except in the case of mercury (Figure 2). The $\mathrm{d}_{001}$ values of the different heavy metals-Mt systems are summarized in Table 1 . They are intermediate between the values corresponding to a one-water layer and a two-water layer montmorillonite, possibly due to random interstratification. Thermal analyses provide independent information on water content (Table 2). The DTG traces of the as-synthesized montmorillonite exhibit a strong endothermal peak 
at $\mathrm{T}_{\max }=78{ }^{\circ} \mathrm{C}$ corresponding to dehydration, with a weight loss of $6.4 \%$ of the dry weight, and two peaks at about $420^{\circ} \mathrm{C}$ and $660{ }^{\circ} \mathrm{C}$ which are attributed to clay layers dehydroxylation (Table 2) [54].

After adsorption of heavy metal cations the dehydration peak is still apparent in the DTG curve (Table 3), but often with a high-temperature shoulder between 94 and $188^{\circ} \mathrm{C}$. This event was also endothermal and could correspond to the elimination of a different kind of water molecules, e.g. those strongly bound to the metal cations. The initial water contents were calculated on the basis of these two peaks. They vary in a rather limited range, corresponding to between 2.3 and 2.8 molecules per unit cell. It may be interesting to note that the water content is inversely correlated to the metal ion hydration enthalpy (which is a negative quantity).

Table 4 indicates the amounts of each heavy metal cation adsorbed by the untreated montmorillonite in our conditions. The affinity of the different divalent cations for the montmorillonite adsorbent varies significantly, the lowest one being observed for cadmium and the highest one for zinc.

The affinity data obtained from adsorption values are plotted as a square diagram in Figure 6 (equivalent fraction in ion exchanger, $\mathrm{Z}_{\mathrm{M}^{2+}}$, plotted as a function of equivalent fraction in solution, $\mathrm{S}_{\mathrm{M}^{2+}}$, at equilibrium). It can be seen that only $\mathrm{Zn}^{2+}$ distributes evenly between the solution and the adsorbed phase, while all other cations have a lower affinity for the clay lattice than the original cation, $\mathrm{Na}^{+}$, which is maybe unexpected as many adsorbents favor divalent over monovalent cations. However, a single point is obviously not enough to characterize the behavior of an ion adsorbent, and these data could correspond to several different adsorption mechanisms. In the concentration region that we investigated, the affinity for the clay matrix scales as: 


$$
\left(\mathrm{Na}^{+}, \mathrm{Zn}^{2+}\right)>\left(\mathrm{Co}^{2+}, \mathrm{Ni}^{2+}, \mathrm{Pb}^{2+}\right)>\left(\mathrm{Hg}^{2+}, \mathrm{Cu}^{2+}\right)>\mathrm{Cd}^{2+}
$$

\subsection{Heavy metals-Cys-Mt.}

When heavy metals are adsorbed on the cysteine-montmorillonite, some broadly similar trends are observed for all metals as regards crystalline organization. The $\mathrm{d}_{001}$ value lie in the 1.43 $1.45 \mathrm{~nm}$ range, only slightly modified with respect to the Na-Cys-Mt; two exceptions are CdCys-Mt and $\mathrm{Pb}$-Cys-Mt which undergo a more important interlayer contraction, possibly indicative of a specific cysteine-cation interaction (Figure 2).

In some other respects, heavy metals-Cys-Mt samples exhibit different behaviors. DTG curves distinguish three broad temperature regions (Figure 4 and Figure 5). Before $200^{\circ} \mathrm{C}$ (range 1), the strong endothermic peak corresponding to water desorption was used to evaluate the water content of the samples. Between 200 and $300{ }^{\circ} \mathrm{C}$ (range 3), the sharp exotherm of cysteine degradation was still observed, with little difference from Na-Cys-Mt, except for sample $\mathrm{Cu}$-Cys-Mt where it was displaced to lower temperatures by $-20{ }^{\circ} \mathrm{C}$ and for sample $\mathrm{Hg}$ Cys-Mt where it was displaced to higher temperatures by $90{ }^{\circ} \mathrm{C}$ Figure 5 . We can assume that for both the $\mathrm{Cu}^{2+}$ and $\mathrm{Hg}^{2+}$ cations, the cation-cysteine interaction is significantly different from the other cases, resulting in a higher (for $\mathrm{Cu}^{2+}$ ) and lower (for $\mathrm{Hg}^{2+}$ ) reactivity of cysteine towards oxidative degradation, respectively. This interpretation is comforted by the fact that for Hg-Cys-Mt, two minor peaks can be seen at the same position as in the reference, in addition to the larger ones shifted to high temperature. This is easily explained if a small amount of cysteine is not interacting with the mercury cations.

In the higher temperature range (above $300{ }^{\circ} \mathrm{C}$, range 3 ), the clay dehydroxylation peaks were still apparent, and quantification suggested that the remaining part of the organic matter was also eliminated in this range (there is a correlation between mass loss excesses in the 200 
-300 and $300-800{ }^{\circ} \mathrm{C}$ ranges, with $\rho=0.81$ ). The amount of cysteine was estimated on the basis of the excess mass loss in ranges 2 and 3 with respect to the raw montmorillonite. Table 2 summarizes the quantitative results obtained for these systems. After contact with the heavy metals solutions, the amount of cysteine in the composite material falls from $7.0 \%$ to a value between 4.3 and $4.9 \%$ (Table 2). Once again the $\mathrm{Hg}^{2+}$ cation stands apart from the rest as it allows the composite to keep $6.0 \%$ of cysteine. The corresponding cysteine/metal cation ratios are shown in Figure 7.

\subsubsection{Quantification of TGA results for heavy metals-Cys-Mt results.}

In general, the heavy metal-Cys-Mt systems contain amounts of water intermediate between those of Cys-Mt and raw Mt, namely, between 2.00 and 2.5 water molecules per unit cell. The outliers are $\mathrm{Pb}$-Cys-Mt with 1.66 waters per unit cell, and $\mathrm{Pb}-\mathrm{Cys}-\mathrm{Mt}$ with 2.86 waters per unit cell. The water contents of heavy metal-Cys-Mt are not correlated with those of cysteine-free heavy metal-Mt.

With respect to the as-synthesized montmorillonite, the cysteine-montmorillonite composite is able to adsorb a larger amount of heavy metal cations. It may not be rigorously correct from the thermodynamical point of view to represent the adsorption data on a square diagram giving $\mathrm{Z}_{\mathrm{M}^{2+}}$ as a function of $\mathrm{S}_{\mathrm{M}^{2+}}$, since the adsorption mechanism is not a simple ion exchange (cf. infra). However, this representation is provided in Figure 8, as it allows easy comparison between the selectivities of the various systems. For all heavy metal- Cys-Mt systems, the data points fall above the diagonal line, indicating that the adsorbent now exhibits selectivity for the divalent metal cations, in stark contrast to the case of cysteine-free heavy metal-Mt systems. 


\subsubsection{Spectroscopic data.}

Characteristic framework vibration modes of Si-O-Si (1019 - $\left.1130 \mathrm{~cm}^{-1}\right)$, Si-O-Al (550 $\left.\mathrm{cm}^{-1}\right)$, and $\mathrm{Si}-\mathrm{O}-\mathrm{Mg}\left(400 \mathrm{~cm}^{-1}\right)$ are present in all samples, as they are due to the clay matrix (Figure 9, Table 5). The infrared spectra of Cys-Mt is compared with that of bulk cysteine in Figure 9. It displays a series of bands that can be assigned to the adsorbed cysteine; their assignments are summarized in Table 5 based on the work of Pawlukojc et al. [55]. The bands of the $-\mathrm{NH}_{3}{ }^{+}$and $-\mathrm{COO}^{-}$moieties are shifted by amounts of the order of 10 to $15 \mathrm{~cm}^{-1}$, indicating a different state of bonding of the cysteine molecules in montmorillonite relative to the bulk crystal. The two carboxylate bands are still present, and there is no band that could be assigned to the $\mathrm{C}=\mathrm{O}$ stretch of a protonated carboxylic acid (it would lie in the $1730-1750 \mathrm{~cm}-1$ range). Therefore, cysteine is not in the cationic form, and its adsorption mechanism does not involve cation exchange. Actually, the experiences on $\mathrm{pH}$ dependency showed that the amount of cysteine adsorbed is maximal at $\mathrm{pH} 4.4$ when the amino acid speciation favors the zwitterion, and decreases significantly at lower $\mathrm{pH}$ when it is cationic. This means that even when there is cationic cysteine in the solution, its adsorption by cation exchange is not favored. A very weak signal is observed at about $2590 \mathrm{~cm}^{-1}$ and could be due to the $-\mathrm{SH}$ functions.

The IR spectra of all heavy metals-Cys-Mt systems are very similar to that of Cys-Mt, with only insignificant shifts (data not shown). This appears to mean that the bonding state of cysteine is the same in all systems, at least as regards the carboxylate moiety. We can also precise that data on the thiol function are imprecise and difficult to use due to the low extinction coefficient of the corresponding band. Thus we will not discuss this part of spectra in detail. 
The samples were also characterized by ${ }^{13} \mathrm{C}$ NMR spectroscopy (Figure 10). In the reference spectrum of bulk cysteine, all three carbons give sharp signals, at $30.3 \mathrm{ppm}$ for $\mathrm{C} 1$ (thiol function), $58 \mathrm{ppm}$ for $\mathrm{C} 2$, and $176.1 \mathrm{ppm}$ for $\mathrm{C} 3$ (carboxylate). The same signals can be identified for Cys-Mt and heavy metals-Cys-Mt that were amenable to study, but as shown in Table 6, the $\mathrm{C} 1$ and $\mathrm{C} 2$ signals are split for Cd-Cys-Mt, $\mathrm{Hg}-\mathrm{Cys}-\mathrm{Mt}, \mathrm{Pb}-\mathrm{Cys}-\mathrm{Mt}$, and possibly also for Zn-Cys-Mt. This suggests the coexistence of two populations of cysteine in different bonding states in these samples. The shift is stronger for $\mathrm{C} 1$ than for $\mathrm{C} 2$, and at first sight this might indicate that the difference concerns the bonding state of the thiol, but the response of the different carbons of an amino acid to bonding is sometimes counterintutive $\mathrm{e}^{50}$.

No spectra could be acquired for Co-Cys-Mt, Ni-Cys-Mt or Cu-Cys-Mt, due to the strong paramagnetic interaction with the metal cation.

\subsubsection{Molecular Modeling.}

The molecular state of cysteine and metal cations was studied for three different systems: $\mathrm{Cd}^{2+}, \mathrm{Pb}^{2+}$, and $\mathrm{Zn}^{2+}-\mathrm{Cys}-\mathrm{Mt}($ Figure 11, Table 7).

For each heavy metal cation, we tested three possible modes of interaction with the cysteine, in 4-coordinated metal-ligand complexes: through the carboxylate moiety, in a chelating mode (carboxylate + thiol), and only through the thiol function. Actually in some cases siloxane oxygens from the clay layers above and below the complex may be considered to act as ligands, yielding a (4+2)-coordinated complex, but they are not shown in the Figure 11 for the sake of clarity.

The Cys/metal ratio was 2 except for the chelate, vacant coordination positions were filled with $\mathrm{H}_{2} \mathrm{O}$ molecules. The optimized conformations obtained after energy minimization are 
shown in Figure 11. It should be noted that in some cases metal-ligand bonds were broken in the course of optimization. For instance the initially chelating cysteine in $\left[\mathrm{Pb}(\mathrm{Cys})_{2}\right]^{2+}$ essentially lost the thiol- $\mathrm{Pb}^{2+}$ interaction, ant the thiol-bound $\mathrm{Pb}^{2+}$ complex unexpectedly ended up as the tricoordinated $\left[\mathrm{Pb}(\mathrm{Cys})_{2}\left(\mathrm{H}_{2} \mathrm{O}\right)\right]^{2+}$.

For $\mathrm{Cd}^{2+}$-Cys-Mt (with 13 water molecules per super cell), the thiol-bound form is the most stable. The Cd-S distance is $2.47 \AA$, with an interaction energy of $-5.83 \mathrm{eV}$. For $\mathrm{Pb}^{2+}$ and $\mathrm{Zn}^{2+}$, 12 and 13 water molecules per super cell are present, respectively, in the interlayer space. In both cases cysteine prefers to interact with the interlayer $\mathrm{Pb}^{2+}$ cation via the carboxylate oxygen rather than the thiol sulfur. The interaction energy between $\mathrm{Pb}^{2+}$ and Cysteine is $-5.60 \mathrm{eV}$, the $\mathrm{Pb}-\mathrm{O}$ distance is $2.4 \AA$ and the $\mathrm{Pb}-\mathrm{S}$ is distance $2.7 \AA$. In the case of $\mathrm{Zn}^{2+}$, the interaction energy is $-5.90 \mathrm{eV}$ and the $\mathrm{Zn}-\mathrm{O}$ distance is $1.96 \AA$.

From the above results one can write the following series for the interaction energy, i.e. the affinity of cysteine to the clay interlayer cation:

$$
\mathrm{Zn}^{2+}>\mathrm{Cd}^{2+}>\mathrm{Pb}^{2+}
$$

$\mathrm{Zn}^{2+}$ has the highest affinity for cysteine, closely followed by $\mathrm{Cd}^{2+}$, which follows the trend calculated by Belcastro et al (2005) [41] for the cations in the gas phase. The weakest interaction with cysteine is found for the $\mathrm{Pb}^{2+}$ cation. This is to be compared with the affinity based on partition coefficients as determined above: $\mathrm{Zn}^{2+}>\mathrm{Pb}^{2+}>\mathrm{Cd}^{2+}$. The difference can most probably be assigned to the fact that the experimental trend is estimated for adsorption from an aqueous phase.

As regards the lattice parameters listed in Table 7 the values of $a, b$ and $\gamma$, which depend on the atomic positions in the clay layer, are almost unaffected by the contents of the interlayer, 
as could be expected. Changes in $\alpha$ and $\beta$ indicate that successive layers may undergo slight displacements relative to each other.

The optimized values of $\mathrm{c}$ on the other hand are significantly smaller (by $1-1.8 \AA$ ) than the experimentally observed ones (compare data in Tables 1 and 7). It is interesting to note that for the metal-Mt systems without cysteine, although the calculated c values are also smaller than the experimental ones, the discrepancy is not as large (0.2 - $1 \AA$ smaller). In other words, the optimization process has caused the clay layers to collapse on the flat-lying $\left[\mathrm{M}(\mathrm{Cys})_{2}\left(\mathrm{H}_{2} \mathrm{O}\right)_{\mathrm{x}}\right]^{2+}$ complexes. While such a process is intuitively reasonable, it remains that in real samples something is holding the layers further apart than expected from the calculations. It could be that part of the cysteine molecules are "standing up" in the interlayer, while the others are lying flat and coordinated to the metal cations. This hypothesis might be in line with the fact that experimental results (IR and NMR) do not agree, as a a result of the co-existence of different molecular geometries of the adsorption complex with the clay layer. Although most cysteine species are geometrically parallel to the clay layers, some fraction of the cysteine might be standing perpendicular to the clay layers.

\subsection{Adsorption reversibility and heavy metals retention data.}

Figure 12 presents the quantities of heavy metals retained after washing with either $\mathrm{NaCl}$ or $\mathrm{SrCl}_{2}$ solutions, expressed as percentages of the initially fixed amounts. Not surprisingly, the $\mathrm{SrCl}_{2}$ treatment is more efficient to remove divalent cations from the matrix in all cases. The efficiency of leaching is very different from one cation to the next, with mercury being almost completely removed and cadmium to a large extent.

Heavy metals-Cys-Mt systems always retain comparable or higher metal contents than heavy metals-Mt systems. In the case of $\mathrm{NaCl}$ washing, the better performance of cysteine- 
containing matrices is evident for mercury and to a lesser extent for cadmium retention. The benefits of cysteine are more evident when washing with $\mathrm{SrCl}_{2}$, where four systems out of six show a significant improvement of retention as compared to cysteine-free systems. Yet $\mathrm{SrCl}_{2}$ washing can still leach over $80 \%$ of the adsorbed cations in several instances. When comparing the three systems that were the object of our modeling study, the order of metal retention was $\mathrm{Zn}^{2+} \approx \mathrm{Pb}^{2+}>\mathrm{Cd}^{2+}$ for heavy metals-Mt systems, but it is altered in the presence of cysteine where the retention of $\mathrm{Pb}^{2+}$ and $\mathrm{Cd}^{2+}$ becomes more efficient.

From an empirical point of view, the introduction of cysteine in a composite material has indeed a positive effect on heavy metal ions trapping. While the raw clay (Mt) has only little affinity for all ions tested, the Cys-Mt complex does show a significant preference for all of them over $\mathrm{Na}^{+}$. In fact, the differences between adsorbed amounts of all heavy metals tested were rather marginal.

This may indicate that interlayer cysteine is able to form coordination complexes with high affinity for all tested heavy metal cations. Table 8 lists complexation constants for $(\mathrm{M}(\mathrm{Cys}) \mathrm{x})^{2+}$ complexes, and they are indeed quite high, indicating a strong affinity. These data are of course given for complex formation in an aqueous solution, while in our systems complex formation occurs in the interlayer space of a clay material. In solution however $\mathrm{Cu}$ (II)-Cys complexes are very unstable as they are very rapidly converted to polymeric $\mathrm{Cu}(\mathrm{I})$ complexes (Stricks and Kolthoff, 1951) [56]. With proceeding oxidation of L-cysteine, the formation of $\mathrm{Cu}(\mathrm{II})$-cystine complexes can occur alternatively. In our case, Raman spectroscopy spectrum does not evidence the formation of cystine (results not shown), showing the difference of reactivity of the complex in the interlayer space and in solution 
The fixation of heavy metals by our matrices is largely reversible if the samples are washed with solutions of high ionic strength, especially if they contain the divalent cation $\mathrm{Sr}^{2+}$. The amount released is highly variable, depending on the heavy metal cation, with $\mathrm{Hg}^{2+}$ being almost completely removed from cysteine-free montmorillonite. The use of a cysteine-clay composite proved to be beneficial regarding this criterion too, indeed as it increases the amount

Apart from these phenomenological conclusions, one can try to provide a more precise picture of heavy metal-cysteine interaction/bonding, based on spectroscopic data. The IR spectra showed that cysteine is present in a different molecular environment in heavy metalsCys-Mt as compared to bulk cysteine and adsorbed cysteine, as expected if coordination complexes are formed. They also suggest that the carboxylate and ammonium moieties are in very similar environments in all cases. The ammonium is indeed unable to establish coordinative bonds; as regards the carboxylate, it should either be always uncoordinated, or always coordinated. The latter possibility appears more likely. We may recall that no firm conclusions can be drawn from IR regarding the state of bonding of the thiol functional group.

${ }^{13} \mathrm{C}$ NMR data are compatible with IR in that the signal of the carboxylate moiety is similar between the four heavy metals-Cys-Mt that could be studied by this technique. Conversely, the carbon bearing the thiol functional group undergoes significant shifts in some samples; or rather, it shows the coexistence of shifted and un-shifted signals, which might correspond to coordinated and uncoordinated thiols. This point may be discussed in relation to the cysteine/heavy metal ratio, which stands at 1.5 to 1.8 in most cases. This ratio seemed to be closer to 2 and was the basis for our choice of coordinating two cysteine molecules in molecular modeling. However, we have proposed earlier that coordinated cysteine molecules could coexist with uncoordinated ones standing upright in the interlayer, and accounting for the high $\mathrm{d}_{001}$ values. If this is true, the cysteine/metal ratio in the complexes should be closer to $1: 1$. 
This caveat must be taken into account when comparing experimental data with the predictions of molecular modeling. According to the latter, the energetically favored form should be a thiol-bound complex in the case of $\mathrm{Cd}^{2+}$, and a carboxylate-bound complex for $\mathrm{Pb}^{2+}$ and $\mathrm{Zn}^{2+}$. The preferential coordination of $\mathrm{Cd}^{2+}$ with the thiol function is indeed compatible with the theory of hard and soft acids and bases: being a soft acid, $\mathrm{Cd}^{2+}$ tends to coordinate to the softer base, while $\mathrm{Zn}^{2+}$ and $\mathrm{Pb}^{2+}$ are borderline acids and thus may coordinate to the harder carboxylate [57]. However, the IR data suggest instead that the carboxylate is coordinated in all cases, while the thiol may be coordinated or not. This discrepancy could possibly be due to the fact that we adopted a 2:1 cysteine:metal ratio instead of a 1:1 ratio. The cysteine orientation within the clay interlayers must also be taken into account. Although the most stable geometries of cysteine-M complex in the clay is orientated parallel to the layers, some complexes might be metastable, oriented perpendicular to the clay layers, due to entropic/steric effects.

\section{Conclusion}

In conclusion, composite adsorptive materials based on cysteine and montmorillonite have been successfully prepared and characterized in depth. The raw montmorillonite and the composites were tested for heavy metal retention. The experimental results indicate the capacity of our composites to chelate heavy metal cations. Indeed, a high affinity between the cysteine and all heavy metal cations was observed. In contrast, in the absence of cysteine, in general, the affinity is very low between the cations and the clay mineral. The chelation in presence of this amino-acid has a direct effect on the release of the cations in water. All cations are strongly bounded to the composites which is not the case for the pristine clay mineral. NMR spectra highlighted the presence of complexes via the shifts observed for the different 
functional groups $\left(\mathrm{C}-\mathrm{SH}\right.$ and $\left.\mathrm{COO}^{-}\right)$. Theoretical calculations are compatible with the experimental observations and allow the identification of the most stable configuration between the functional groups and the cations.

In summary, it is possible to experimentally assess the molecular-level state of cysteineheavy metals complexes, thanks to the information obtained from spectroscopic methods and theoretical calculations on these systems. A fully consistent picture of heavy metals speciation in these systems should combine information from these two sources and has not yet been reached.

\section{Acknowledgements}

This work was performed using HPC resources from GENCI- [CCRT/CINES/IDRIS] (Grant 2014-[x2014082022]) and the CCRE of Université Pierre et Marie Curie. Dr. B. Diawara from LCPS ENS Paris is kindly acknowledged for providing us with ModelView used in the visualization of the structures.

\section{Author information}

Corresponding authors

*Maguy Jaber : maguy.jaber@upmc.fr

Notes

The authors declare no competing financial interest. 


\section{References}

[1] W.R. Berti, L.W. Jacobs, Distribution of trace elements in soil from repeated sewage sludge application., J. Environ. Qual., 27 (1996) 1280-1286.

[2] M.M. de Oliveira, M.M. Fernandes, M.G. Fonseca, E.C. da Silva Filho, A.G. de Souza, F. Gaslain, M. Jaber, Direct grafting of ethylene sulfide onto silicic acid magadiite, Micropor. Mesopor. Mat., 196 (2014) 292-299.

[3] S. Mintova, M. Jaber, V. Valtchev, Nanosized microporous crystals: emerging applications, Chem. Soc. Rev., 44 (2015) 7207-7233.

[4] A. Iyer, K. Mody, B. Jha, Biosorption of heavy metals by a marine bacterium, Mar. Pollut. Bull., 50 (2005) 340-343.

[5] M. Valls, V.c. de Lorenzo, Exploiting the genetic and biochemical capacities of bacteria for the remediation of heavy metal pollution, FEMS Microbiol. Rev., 26 (2002) 327-338.

[6] A.G. Khan, C. Kuek, T.M. Chaudhry, C.S. Khoo, W.J. Hayes, Role of plants, mycorrhizae and phytochelators in heavy metal contaminated land remediation, Chemosphere, 41 (2000) 197-207.

[7] P. Xu, G.M. Zeng, D.L. Huang, C.L. Feng, S. Hu, M.H. Zhao, C. Lai, Z. Wei, C. Huang, G.X. Xie, Z.F. Liu, Use of iron oxide nanomaterials in wastewater treatment: A review, Sci. Total Environ., 424 (2012) 1-10.

[8] L. Cumbal, A.K. SenGupta, Arsenic Removal Using Polymer-Supported Hydrated Iron(III) Oxide Nanoparticles: Role of Donnan Membrane Effect†, Environ. Sci. Technol., 39 (2005) $6508-6515$ 
[9] X.-q. Li, W.-x. Zhang, Sequestration of Metal Cations with Zerovalent Iron NanoparticlesA Study with High Resolution X-ray Photoelectron Spectroscopy (HR-XPS), J. Phys. Chem. C, $111(2007) 6939-6946$.

[10] J.-f. Liu, Z.-s. Zhao, G.-b. Jiang, Coating Fe3O4 Magnetic Nanoparticles with Humic Acid for High Efficient Removal of Heavy Metals in Water, Environ. Sci. Technol., 42 (2008) 69496954.

[11] X. Chen, J. Wright, J. Conca, L. Peurrung, Evaluation of heavy metal remediation using mineral apatite, Water Air Soil Pollut., 98 (1997) 57-78.

[12] K.G. Bhattacharyya, S. Sen Gupta, Adsorption of a few heavy metals on natural and modified kaolinite and montmorillonite: A review, Adv. Coll. Interf. Sci., 140 (2008) 114-131. [13] X. Cai, Y. Gao, Q. Sun, Z. Chen, M. Megharaj, R. Naidu, Removal of co-contaminants $\mathrm{Cu}$ (II) and nitrate from aqueous solution using kaolin-Fe/Ni nanoparticles, Chem. Eng. J., 244 (2014) 19-26.

[14] T. Falayi, F. Ntuli, Removal of heavy metals and neutralisation of acid mine drainage with un-activated attapulgite, J. Ind. Eng. Chem., 20 (2014) 1285-1292.

[15] M. Haitzer, G.R. Aiken, J.N. Ryan, Binding of mercury(II) to aquatic humic substances: Influence of pH and source of humic substances. , Environ. Sci. Technol. , 37 (2003) 24362441.

[16] M. Jaber, J. Miehe-Brendle, L. Delmotte, R. Le Dred, New range of Al-Mg organoclays with tailored hydrophobicity: incorporation of fluoride as a local probe to study the octahedral character, Micropor. Mesopor. Mater., 65 (2003) 155-163.

[17] M. Jaber, J. Miehe-Brendle, R. Le Dred, Mercaptopropyl Al-Mg phyllosilicate: Synthesis and characterization by XRD, IR, and NMR, Chem. Lett., (2002) 954-955. 
[18] M. Jaber, J. Miehe-Brendle, R. Le Dred, New lamellar Si-Al inorganic-organic hybrid material, J. Mater. Sci., 39 (2004) 1489-1490.

[19] M. Jaber, J. Miehe-Brendle, L. Michelin, L. Delmotte, Heavy metal retention by organoclays: Synthesis, applications, and retention mechanism, Chem. Mater., 17 (2005) 52755281.

[20] M. Jaber, T. Georgelin, H. Bazzi, F. Costa-Torro, J.-F. Lambert, G. Bolbach, G. Clodic, Selectivities in Adsorption and Peptidic Condensation in the (Arginine and Glutamic Acid)/Montmorillonite Clay System, J. Phys. Chem. C, 118 (2014) 25447-25455.

[21] S.S.G. Santosa, M.B.B. Pereiraa, R.K.S. Almeidab, A.G. Souzaa, M.G. Fonseca, M. Jaber, Silylation of leached-vermiculites following reaction with imidazole and copper sorption behavior, J. Hazard. Mater., 306 (2016) 406-418.

[22] P.W. Schindler, B. Fürst, R. Dick, P.U. Wolf, J. Colloid Interface Sci. , 55 (1976) 469.

[23] P.E. Blochl, O. Jepsen, O.K. Andersen, Improved tetrahedron method for Brillouin-zone integrations, Phys. Rev. B, 49 (1994) 16223-16233.

[24] F. Tielens, M. Trejda, M. Ziolek, S. Dzwigaj, Nature of vanadium species in V substituted zeolites: A combined experimental and theoretical study, Catal. Today, 139 (2008) 221-226. [25] J. Singh, P.M. Huang, U.T. Hammer, W.K. Liaw, Influence of citric acid and glycine on the adsorption of mercury(II) by kaolinite under various $\mathrm{pH}$ conditions., Clays Clay Min., 44 (1996) 41-48.

[26] M. Bouchoucha, M. Jaber, T. Onfroy, J.-F. Lambert, B. Xue, Glutamic Acid Adsorption and Transformations on Silica, J. Phys. Chem. C, 115 (2011) 21813-21825. 
[27] T. Georgelin, M. Jaber, H. Bazzi, J.-F. Lambert, Formation of Activated Biomolecules by Condensation on Mineral Surfaces - A Comparison of Peptide Bond Formation and Phosphate Condensation, Origins Life and Evol. Biospheres, 43 (2013) 429-443.

[28] M. Jaber, M. Bouchoucha, L. Delmotte, C. Methivier, J.-F. Lambert, Fate of L-DOPA in the Presence of Inorganic Matrices: Vectorization or Composite Material Formation?, J. Phys. Chem. C, 115 (2011) 19216-19225.

[29] M. Jaber, J.-F. Lambert, A New Nanocomposite: L-DOPA/Laponite, J. Phys. Chem. Lett., $1(2010) 85-88$.

[31] M. Bouchoucha, F. Tielens, F. Gaslain, F. CostaTorro, S. Casale, A. Palcic, V. Valtchev, J.-F. Lambert, M. Jaber, Melanin Polymerization Held in Check: A Composite of Dihydroxyphenylalanine with Zeolite Beta, J. Phys. Chem. C, 119 (2015) 8736-8747.

[32] O. Poch, M. Jaber, F. Stalport, S. Nowak, T. Georgelin, J.-F. Lambert, C. Szopa, P. Coll, Effect of Nontronite Smectite Clay on the Chemical Evolution of Several Organic Molecules under Simulated Martian Surface Ultraviolet Radiation Conditions, Astrobiology, 15 (2015) 221-237.

[33] T. Georgelin, M. Jaber, T. Onfroy, A.-A. Hargrove, F. Costa-Torro, J.-F. Lambert, Inorganic Phosphate and Nucleotides on Silica Surface: Condensation, Dismutation, and Phosphorylation, J. Phys. Chem. C, 117 (2013) 12579-12590.

[34] S. Balme, R. Guegan, J.-M. Janot, M. Jaber, M. Lepoitevin, P. Dejardin, X. Bourrat, M. Motelica-Heino, Structure, orientation and stability of lysozyme confined in layered materials, Soft Matter, 9 (2013) 3188-3196.

[35] A. Assifaoui, L. Huault, C. Maissiat, C. Roullier-Gall, P. Jeandet, J. Hirschinger, J. Raya, M. Jaber, J.-F. Lambert, P. Cayot, R.D. Gougeon, C. Loupiac, Structural studies of adsorbed 
protein (betalactoglobulin) on natural clay (montmorillonite), RSC Adv., 4 (2014) 6109661103.

[36] G. Berthon, ' Critical Evaluation of the Stability Constants of Metal Complexes of Amino Acids with Polar Side Chains, Pure Appl. Chem. , 67 (1995) 1117-1240.

[37] H. de Santana, A. Paesano, Jr., A.C.S. da Costa, E. di Mauro, I.G. de Souza, F.F. Ivashita, C.M.D. de Souza, C.T.B.V. Zaia, D.A.M. Zaia, Cysteine, thiourea and thiocyanate interactions with clays: FT-IR, Mossbauer and EPR spectroscopy and X-ray diffractometry studies, Amino Acids, 38 (2010) 1089-1099.

[38] W. Levason, C.A. McAuliffe, S.G. Murray, Tris(ethylenediamine)cobalt(III) hexachloromanganate dihydrate, Inorg. Nucl. Chem. Letters, 8 (1972) 97-100.

[39] M.F. Brigatti, S. Colonna, D. Malferrari, L. Medici, L. Poppi, Mercury adsorption by montmorillonite and vermiculite: a combined XRD, TG-MS, and EXAFS study, Appl. Clay Sci., 28 (2005) 1-8.

[40] M.F. Brigatti, D. Malferrari, L. Medici, L. Poppi, Effect of amino acids on the retention of copper by beidellite, Environ.Eng. Sci., 20 (2003) 601-606.

[41] M. Belcastro, T. Marino, N. Russo, M. Toscano, Interaction of cysteine with $\mathrm{Cu} 2+$ and Group IIb (Zn2+, Cd2+, Hg2+) metal cations: a theoretical study, J. Mass Spectrom., 40 (2005) 300-306.

[42] A. Chatterjee, T. Ebina, F. Mizukami, Effects of water on the structure and bonding of resorcinol in the interlayer of montmorillonite nanocomposite: A periodic first principle study, J. Phys. Chem. B, 109 (2005) 7306-7313.

[43] A. Chatterjee, T. Iwasaki, T. Ebina, A. Miyamoto, A DFT study on clay-cation-water interaction in montmorillonite and beidellite, Comp. Mater. Sci., 14 (1999) 119-124. 
[44] K. El Adraa, V. Timon, J.-F. Lambert, A.-R. Al-Rabaa, F. Jaber, M. Jaber, F. Tielens, Adsorption of L-DOPA Intercalated in Hydrated Na-Saponite Clay: A Combined Experimental and Theoretical Study, J. Phys. Chem. C, 116 (2012) 26414-26421.

[45] M. Reinholdt, J. Miehe-Brendle, L. Delmotte, R. Le Dred, M.H. Tuilier, Synthesis and characterization of montmorillonite-type phyllosilicates in a fluoride medium, Clay Miner., 40 (2005) 177-190.

[46] G. Kresse, J. Hafner, Ab-Initio Molecular-Dynamics for Open-Shell Transition-Metals, Phys. Rev. B, 48 (1993) 13115-13118.

[47] G. Kresse, J. Hafner, Ab-initio molecular-dynamics simulation of the liquid-metal amorphous-semiconductor transition in germanium, Phys. Rev. B, 49 (1994) 14251-14269.

[48] J.P. Perdew, K. Burke, M. Ernzerhof, Generalized gradient approximation made simple, Phys. Rev. Lett., 77 (1996) 3865-3868.

[49] J.P. Perdew, K. Burke, M. Ernzerhof, Generalized gradient approximation made simple (vol 77, pg 3865, 1996), Phys. Rev. Lett., 78 (1997) 1396-1396.

[50] M. Calatayud, F. Tielens, F. De Proft, Reactivity of gas-phase, crystal and supported V2O5 systems studied using density functional theory based reactivity indices, Chem. Phys. Lett., 456 (2008) 59-63.

[51] G. Kresse, D. Joubert, From ultrasoft pseudopotentials to the projector augmented-wave method, Phys. Rev. B, 59 (1999) 1758-1775.

[52] D. Gournis, A. Lappas, M.A. Karakassides, D. Tobbens, A. Moukarika, A neutron diffraction study of alkali cation migration in montmorillonites, Phys. Chem. Miner., 35 (2008) 49-58. 
[53] M. Lepoitevin, M. Jaber, R. Guegan, J.-M. Janot, P. Dejardin, F. Henn, S. Balme, BSA and lysozyme adsorption on homoionic montmorillonite: Influence of the interlayer cation, Appl. Clay Sci., 95 (2014) 396-402.

[54] F. Tielens, J. Andres, T.D. Chau, T.V. de Bocarme, N. Kruse, P. Geerlings, Molecular oxygen adsorption on electropositive nano gold tips, Chem. Phys. Lett., 421 (2006) 433-438.

[55] A. Pawlukojć, J. Leciejewicz, A.J. Ramirez-Cuesta, J. Nowicka-Scheibe, 1-Cysteine: Neutron spectroscopy, Raman, IR and ab initio study, Spectrochim. Acta A, 61 (2005) 24742481.

[56] W. Stricks, I.M. Kolthoff, Polarographic investigations of reactions in aqueous solutions containing copper and cysteine(Cystine). I. Cuprous copper and cysteine in ammoniacal medium. The dissociation constant of cupreous cysteinate, J. Am. Chem. Soc., 73 (1951) 17231733.

[57] S. Hoyau, K. Norrman, T.B. McMahon, G. Ohanessian, A quantitative basis for a scale of $\mathrm{Na}+$ affinities of organic and small biological molecules in the gas phase, J. Am. Chem.1 Soc., 121 (1999) 8864-8875. 
Table 1: Variation of the $d_{001}$ as a function of the cation, its ionic radius and its hydration state.

\begin{tabular}{|c|c|c|c|c|c|}
\hline \multirow[t]{2}{*}{ Cation } & \multirow{2}{*}{$\begin{array}{c}\text { Ionic } \\
\text { Radius (nm) }\end{array}$} & \multirow{2}{*}{$\begin{array}{c}\text { Hydration } \\
\text { Energy }\left(\mathrm{kJ} \cdot \mathrm{mol}^{-1}\right)\end{array}$} & \multicolumn{2}{|l|}{$\mathrm{d}_{001}(\mathrm{~nm})$} & \multirow{2}{*}{\begin{tabular}{l}
\multicolumn{1}{c}{$\# \mathrm{H}_{2} \mathrm{O}$} \\
(molecules) \\
/unit cell
\end{tabular}} \\
\hline & & & cations-Mt & $\begin{array}{l}\text { cations- } \\
\text { Cys-Mt }\end{array}$ & \\
\hline $\mathrm{Na}^{+}$ & 0.102 & -444 & 1.23 & 1.49 & 2.7 \\
\hline $\mathrm{Co}^{2+}$ & 0.065 & -1873 & 1.39 & 1.45 & 2.80 \\
\hline $\mathrm{Ni}^{2+}$ & 0.069 & -1880 & 1.35 & 1.45 & 2.80 \\
\hline $\mathrm{Cu}^{2+}$ & 0.073 & -1988 & 1.32 & 1.43 & 2.80 \\
\hline $\mathrm{Zn}^{2+}$ & 0.074 & -1873 & 1.31 & 1.44 & 2.51 \\
\hline $\mathrm{Cd}^{2+}$ & 0.095 & -1694 & 1.31 & 1.39 & 2.80 \\
\hline $\mathrm{Hg}^{2+}$ & 0.102 & -1665 & 1.40 & 1.45 & 2.20 \\
\hline $\mathrm{Pb}^{2+}$ & 0.119 & -1534 & 1.29 & 1.37 & 2.31 \\
\hline
\end{tabular}


Table 2: Quantification of TGA results for metals-Cys-Mt.

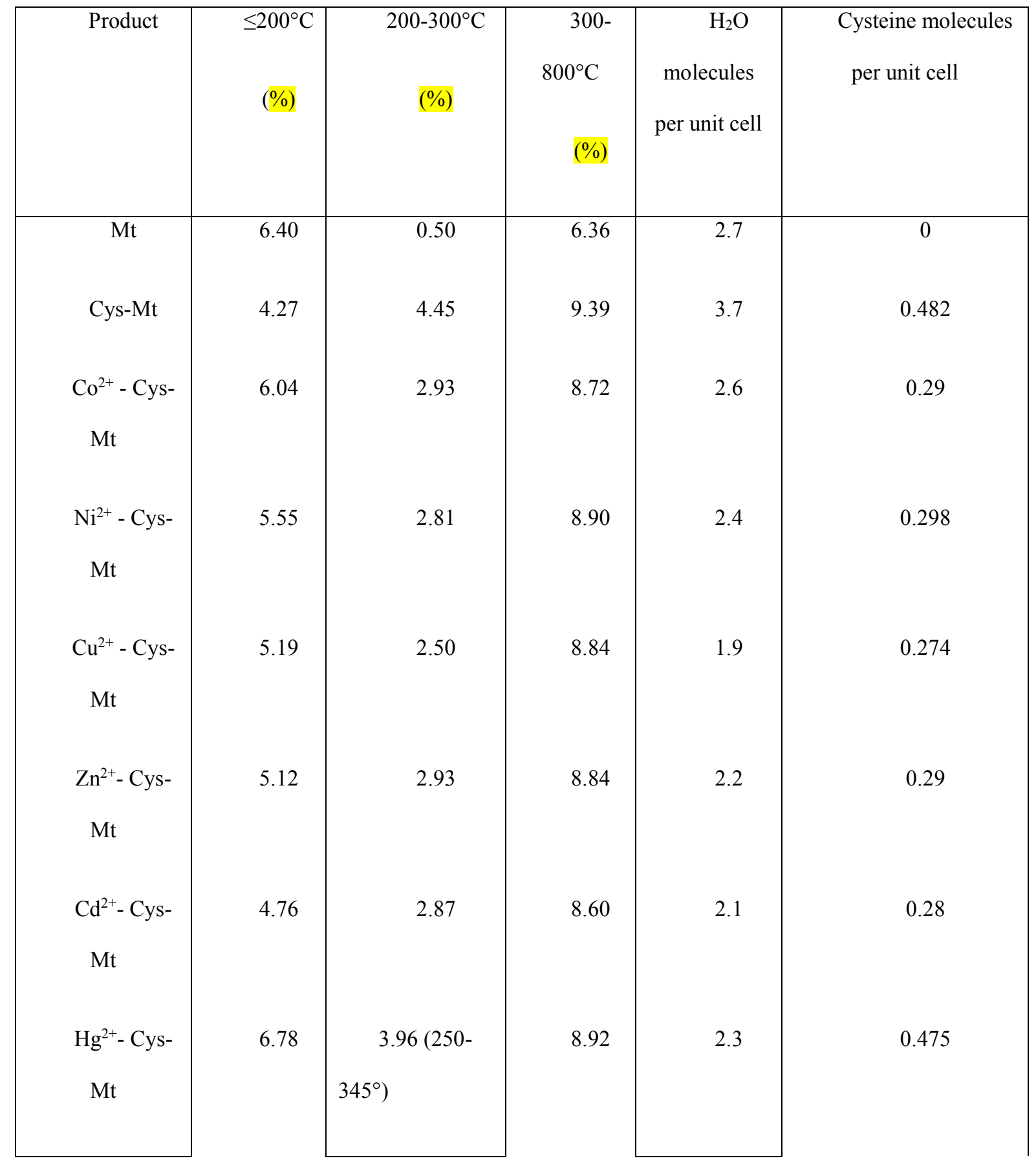




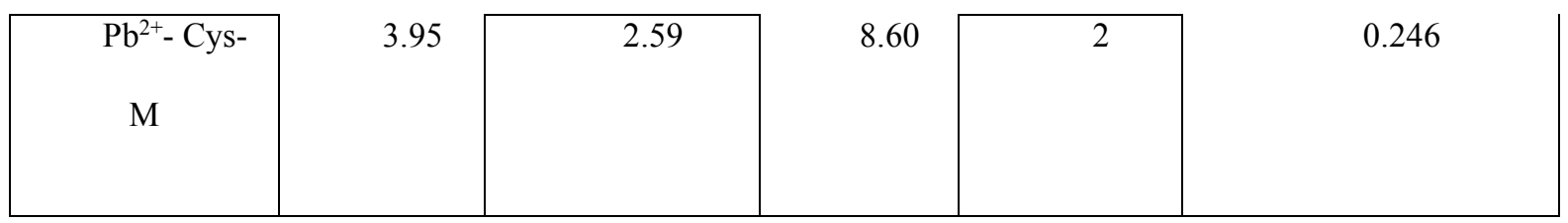

Table 3: Quantification of TGA results for metals-Mt results

\begin{tabular}{|c|c|}
\hline Product & $\leq 200^{\circ} \mathrm{C}$ (weight \%) \\
\hline $\mathrm{Co}^{2+}-\mathrm{Mt}$ & 5.74 \\
$\mathrm{Ni}^{2+}-\mathrm{Mt}$ & 5.02 \\
$\mathrm{Cu}^{2+}-\mathrm{Mt}$ & 5.61 \\
$\mathrm{Zn}^{2+}-\mathrm{Mt}$ & 5.19 \\
$\mathrm{Cd}^{2+}-\mathrm{Mt}$ & 5.59 \\
$\mathrm{Hg}^{2+}-\mathrm{Mt}$ & 6.51 \\
$\mathrm{~Pb}^{2+}-\mathrm{Mt}$ & 5.05 \\
\hline
\end{tabular}


Table 4: Quantitative data for heavy metal adsorption in heavy metal-Mt and heavy metal-Cys-Mt systems. Note that the adsorbed amounts in mmol/g can be transformed into meq/100g by simply multiplying by 200, as all cations are divalent. The clay CEC is 52.77 meq/loog.

\begin{tabular}{|c|c|c|c|c|}
\hline & \multicolumn{2}{|c|}{ Adsorption on $\mathrm{Mt}$} & \multicolumn{2}{|c|}{ Adsorption on Cys-Mt } \\
\hline & $\begin{array}{l}\text { Amount } \\
\text { adsorbed } \\
(\mathrm{mmol} / \mathrm{g})\end{array}$ & $\begin{array}{c}\text { Amount } \\
\text { adsorbed, \% of CEC }\end{array}$ & $\begin{array}{l}\text { Amount } \\
\text { adsorbed } \\
(\mathrm{mmol} / \mathrm{g})\end{array}$ & $\begin{array}{l}\text { Amount adsorbed, \% } \\
\text { of CEC }\end{array}$ \\
\hline $\mathrm{Co}^{2+}$ & 0.178 & 67,5 & 0.219 & 83,0 \\
\hline $\mathrm{Ni}^{2+}$ & 0.176 & 66,7 & 0.228 & 86,4 \\
\hline $\mathrm{Cu}^{2+}$ & 0.144 & 54,6 & 0.242 & 91,7 \\
\hline $\mathrm{Zn}^{2+}$ & 0.211 & 80.0 & 0.235 & 89,1 \\
\hline $\mathrm{Cd}^{2+}$ & 0.073 & 27,7 & 0.225 & 85,3 \\
\hline $\mathrm{Hg}^{2+}$ & 0.147 & 55,7 & 0.229 & 86,8 \\
\hline $\mathrm{Pb}^{2+}$ & 0.173 & 65,6 & 0.231 & 87,6 \\
\hline
\end{tabular}


Table 5: Assignment of vibrations due to cysteine, in bulk cysteine and in Cys-Mt.

\begin{tabular}{|c|c|c|}
\hline & $\begin{array}{l}\text { Bulk cysteine }\left(\mathrm{cm}^{-}\right. \\
\left.{ }^{1}\right)\end{array}$ & Cys-Mt (cm-1) \\
\hline $\mathrm{CH}_{2}$ twist & 1197 & 1192 \\
\hline $\mathrm{CH}_{2}$ wag & 1296 & 1296 \\
\hline $\mathrm{NH}_{3}$ bend sym & 1346 & 1337 \\
\hline $\mathrm{CO}_{2}$ str. Sym & 1397 & 1382 \\
\hline n.a. & 1544 & 1486 \\
\hline $\mathrm{CH}_{2}$ bend & 1424 & 1407 \\
\hline $\mathrm{NH}_{3}$ bend asym & 1587 & 1585 \\
\hline $\mathrm{NH}_{3}$ bend asym & 1609 & 1632 \\
\hline $\mathrm{CO}_{2}$ str. asym. & 1649 (sh) & 1657 \\
\hline SH str & 2551 & $2590 ?$ \\
\hline
\end{tabular}

Table 6: ${ }^{13}$ C NMR chemical shifts of cysteine carbon in Cys-Mt and heavy metals-Cys-Mt systems. 


\begin{tabular}{|c|c|c|c|}
\hline & $\mathrm{C}_{1}(\mathrm{ppm})$ & $\mathrm{C}_{2}(\mathrm{ppm})$ & $\mathrm{C}_{3}(\mathrm{ppm})$ \\
\hline Bulk Cys & 30.4 & 58.4 & 175.8 \\
\hline Cys-Mt & 37.6 & 56.0 & 177.5 \\
\hline Zn-Cys-Mt & 35.0 & 53.45 & 174.8 \\
\hline \multirow[t]{2}{*}{ Cd-Cys-Mt } & 35.5 & 58.95 & 175.1 \\
\hline & 17.3 & 53.8 & $173.7 ?$ \\
\hline \multirow[t]{2}{*}{$\mathrm{Hg}-\mathrm{Cys}-\mathrm{Mt}$} & 35.5 & 60.0 & 175.1 \\
\hline & 19.5 & 56.85 & \\
\hline \multirow[t]{2}{*}{$\mathrm{Pb}-\mathrm{Cys}-\mathrm{Mt}$} & 35.2 & 58.4 & 174.8 \\
\hline & 17.6 & 53.55 & \\
\hline
\end{tabular}

Table 7: Calculated lattice parameter values for the heavy metals-Mt and heavy metalsCys-Mt systems.

\begin{tabular}{|l|r|r|r|r|r|r|}
\hline & $\mathrm{a}(\AA)$ & $\mathrm{b}(\AA)$ & $\mathrm{c}(\AA)$ & $\alpha\left(^{\circ}\right)$ & $\beta\left(^{\circ}\right)$ & $\gamma\left(^{\circ}\right)$ \\
\hline $\mathrm{Na}^{+}-\mathrm{Mt}$ & 10.46 & 27.09 & 12.11 & 88.40 & 89.63 & 89.99 \\
$\mathrm{Cd}^{2+}-\mathrm{Mt}$ & 10.45 & 27.04 & 12.05 & 85.71 & 90.81 & 89.95 \\
& & & & & & \\
$\mathrm{Cd}^{2+}$ cysteine-Mt & 10.40 & 26.93 & 12.90 & 84.85 & 87.66 & 89.99 \\
& & & & & & \\
\cline { 1 - 3 }
\end{tabular}




\begin{tabular}{|l|r|r|r|r|r|r|}
\hline \multicolumn{1}{l|}{$\mathrm{Zn}^{2+}$-Mt } & 10.45 & 27.02 & 12.09 & 84.03 & 89.45 & 89.94 \\
$\mathrm{Zn}^{2+}$ cysteine-Mt & 10.44 & 27.04 & 12.61 & 86.81 & 87.90 & 89.99 \\
$\mathrm{~Pb}^{2+}$-Mt & 10.45 & 27.00 & 12.06 & 86.47 & 88.89 & 89.93 \\
& & & & & & \\
$\mathrm{~Pb}^{2+}$ cysteine-Mt & 10.44 & 27.04 & 12.53 & 88.02 & 89.18 & 89.99 \\
\end{tabular}


Table 8: Complexation constants for $\left(\mathrm{M}(\mathrm{Cys})_{\mathrm{x}}\right)^{2+}$ complexes in aqueous solution where $\mathrm{x}$ $=1,2,3$

\begin{tabular}{|llll|}
\hline Cation & $\mathbf{K}^{\circ}{ }_{\text {ML1 }}$ & $\mathbf{K}^{\circ}{ }_{\text {ML2 }}$ & $\mathbf{K}^{\circ}{ }_{\text {ML3 }}$ \\
\hline $\mathrm{Ni}^{2+}$ & 9.83 & 20.21 & 23.08 \\
$\mathrm{Cu}^{2+}$ & & 16 & \\
$\mathrm{Zn}^{2+}$ & 9.67 & 18.71 & 21.64 \\
$\mathrm{Cd}^{2+}$ & 6.45 & & \\
$\mathrm{Hg}^{2+}$ & 20.5 & 43.75 & \\
$\mathrm{~Pb}^{2+}$ & 12.75 & 16.91 & 19.5 \\
\hline
\end{tabular}




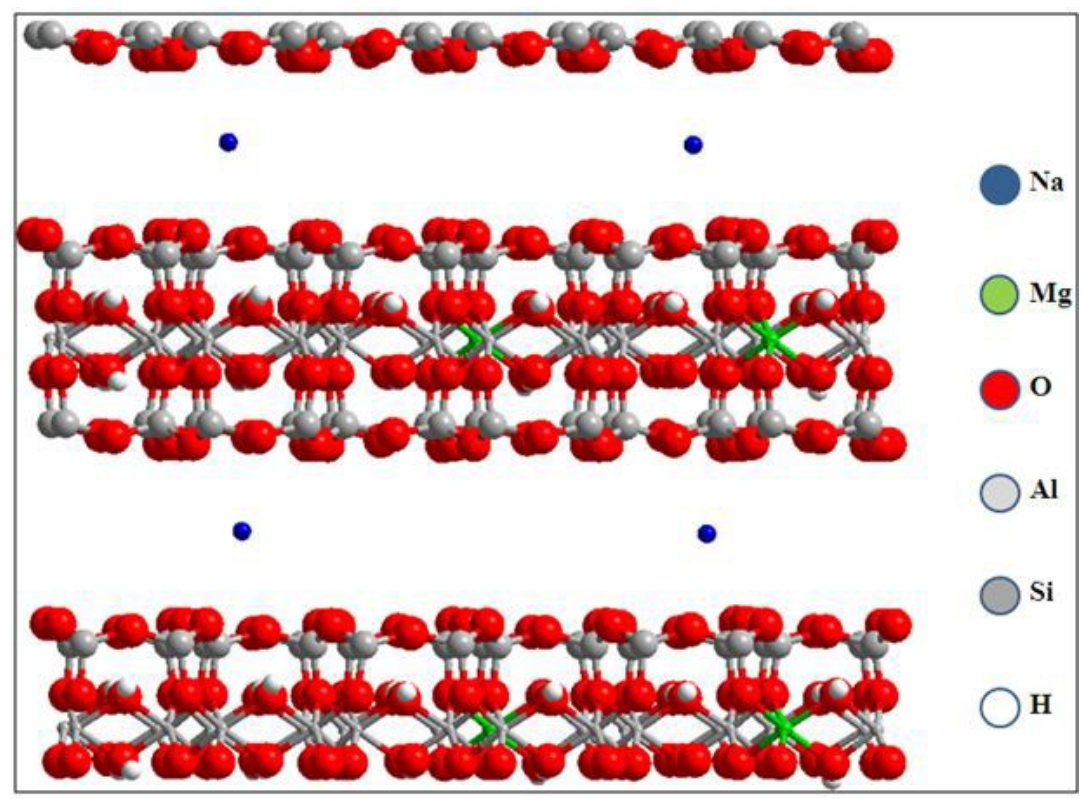

Figure 1: Montmorillonite super cell used in the calculations, shown with a $\mathrm{Na}^{+}$cation.

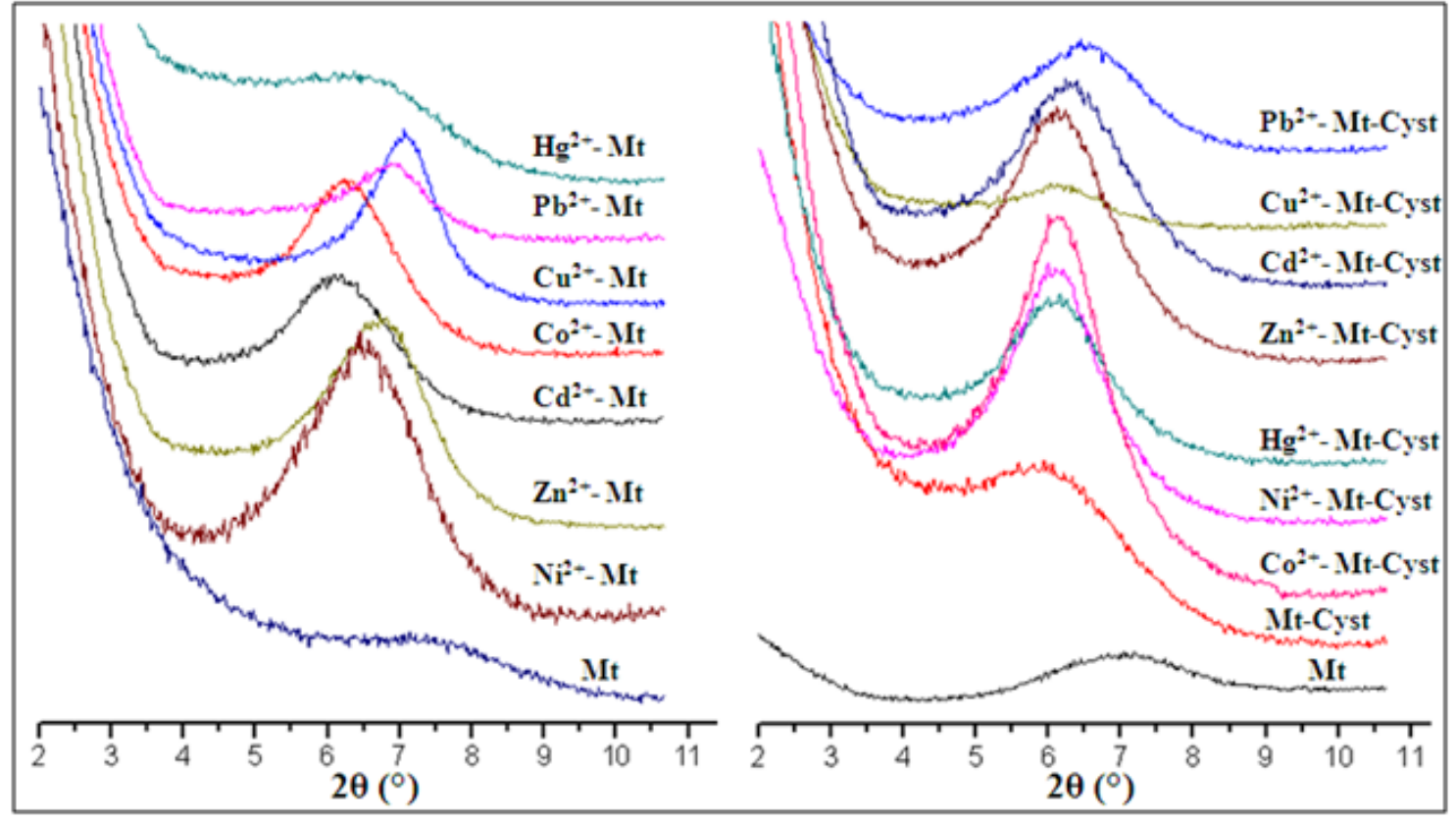

Figure 2 : X-Ray patterns of heavy metals-Mt composites (left) and heavy metals-Cys-Mt composites (right). 


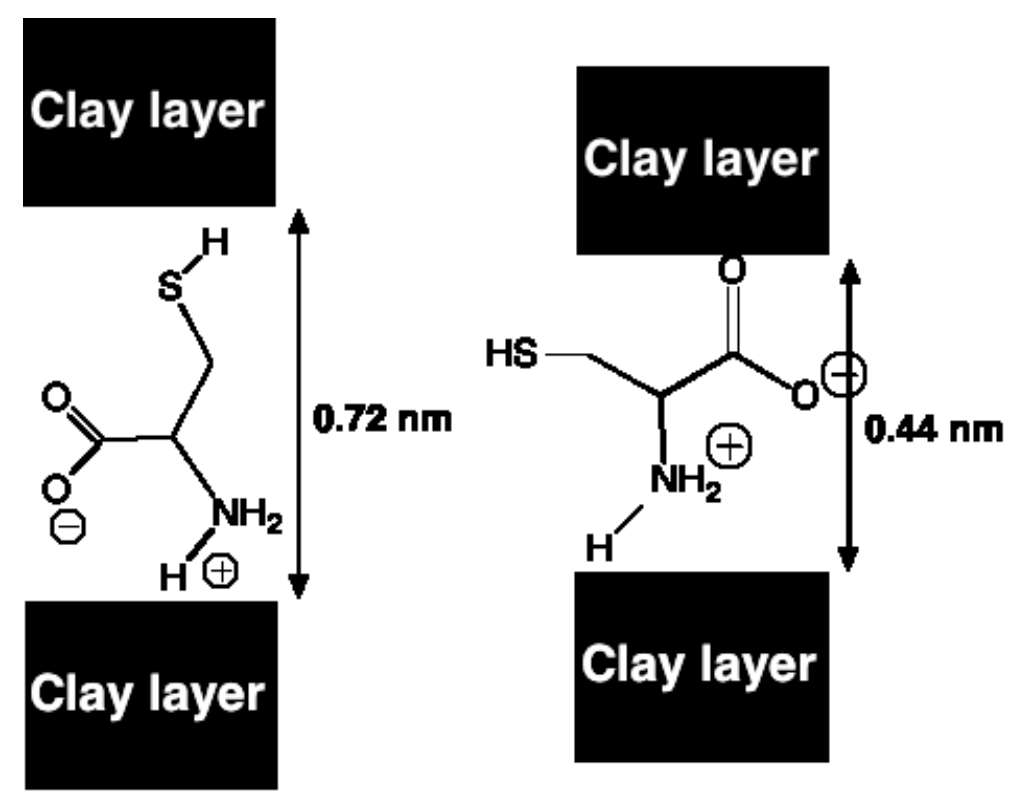

Figure 3: Two possible orientations of cysteine in the interlayer space, and the corresponding expected interlayer distances. 


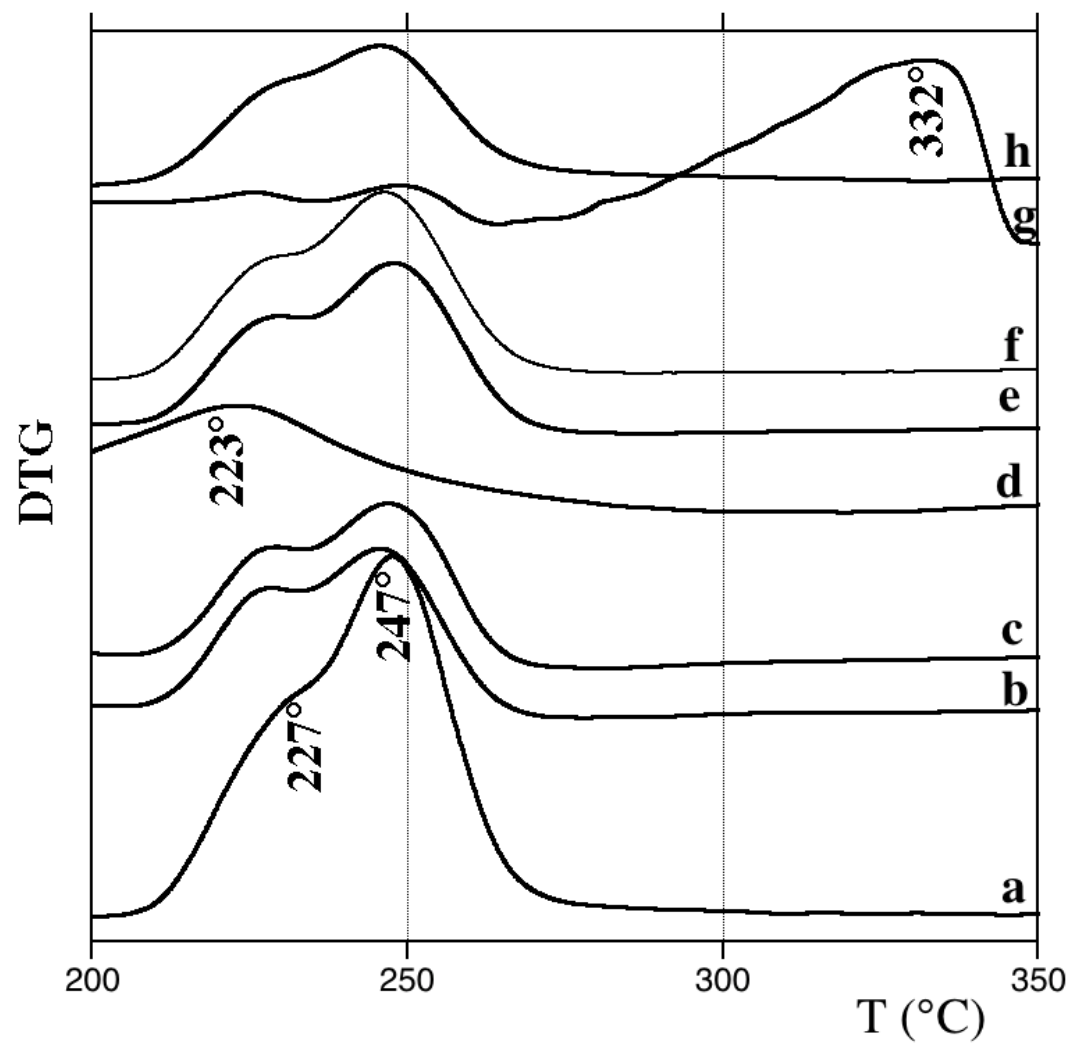

Figure 4: DTG curves, in the $200-350^{\circ} \mathrm{C}$ range (cysteine degradation) of samples: $a$. NaCys-Mt, b. Co-Cys-Mt, c. Ni-Cys-Mt, d. Cu-Cys-Mt, e. Zn-Cys-Mt, f. Cd-Cys-Mt, g. Hg-Cys$M t, h . P b-C y s-M t$. 


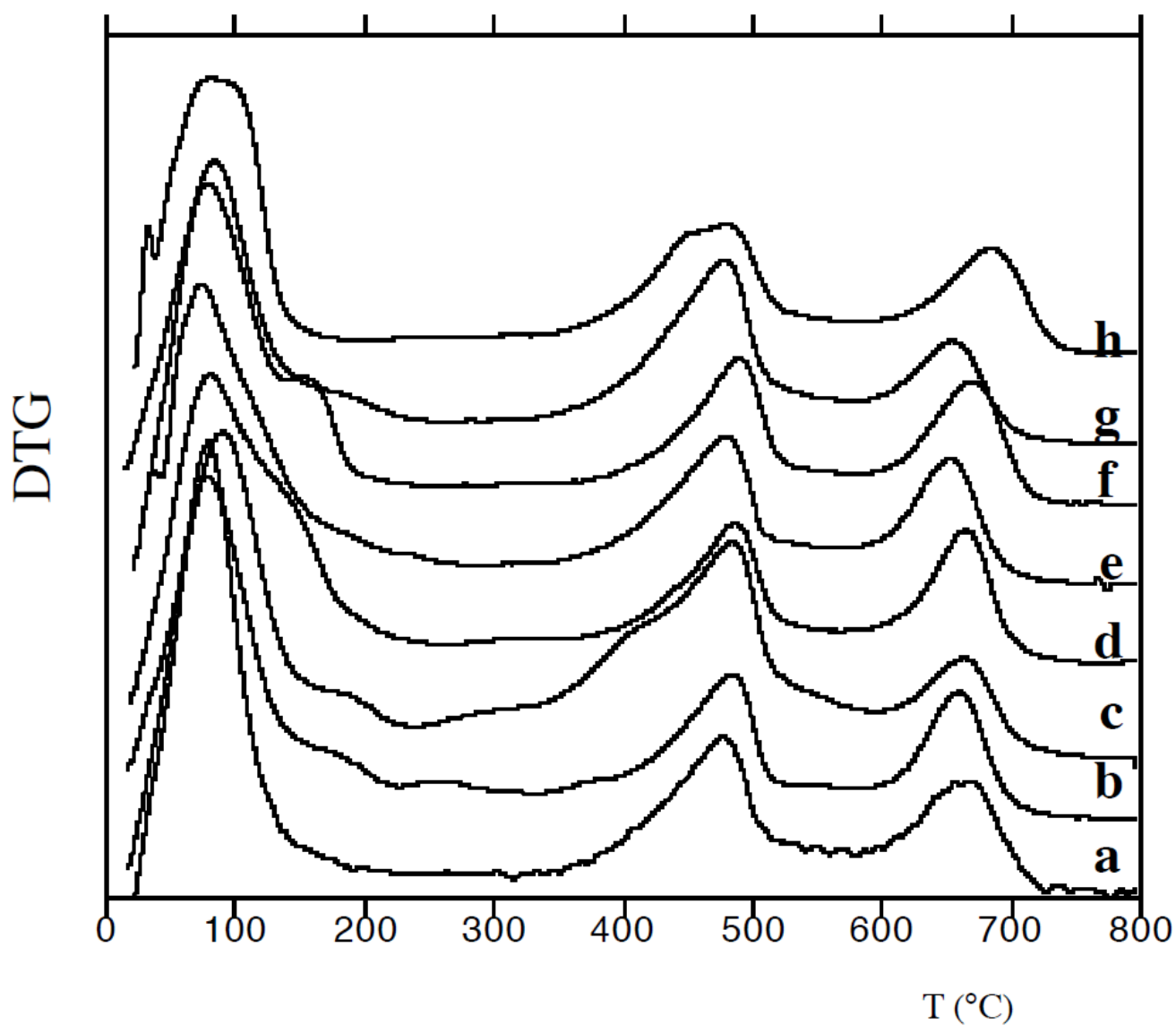

Figure 5: DTG curves, a. Na-Cys-Mt, b. Co-Cys-Mt, c. Ni-Cys-Mt, d. Cu-Cys-Mt, e. ZnCys-Mt, f. Cd-Cys-Mt, g. Hg-Cys-Mt, h. Pb-Cys-Mt. 


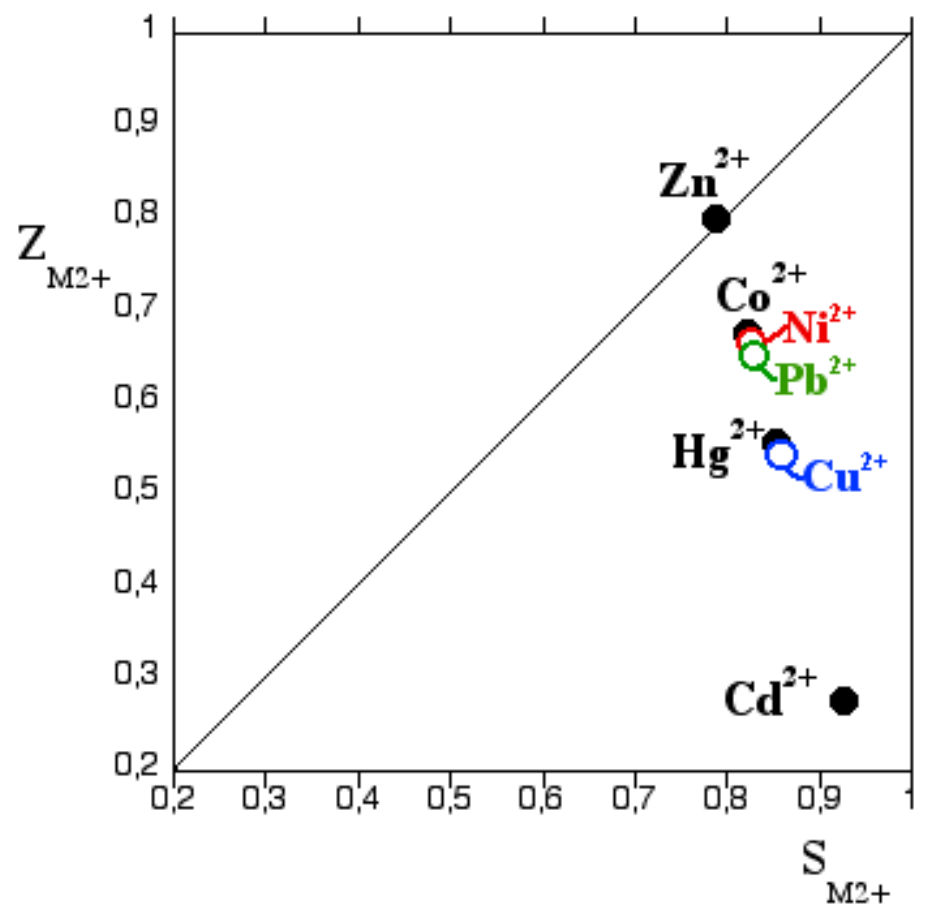

Figure 6: Affinity data for the various metal cation adsorbed on raw (Na) montmorillonite, plotted as a square diagram. 


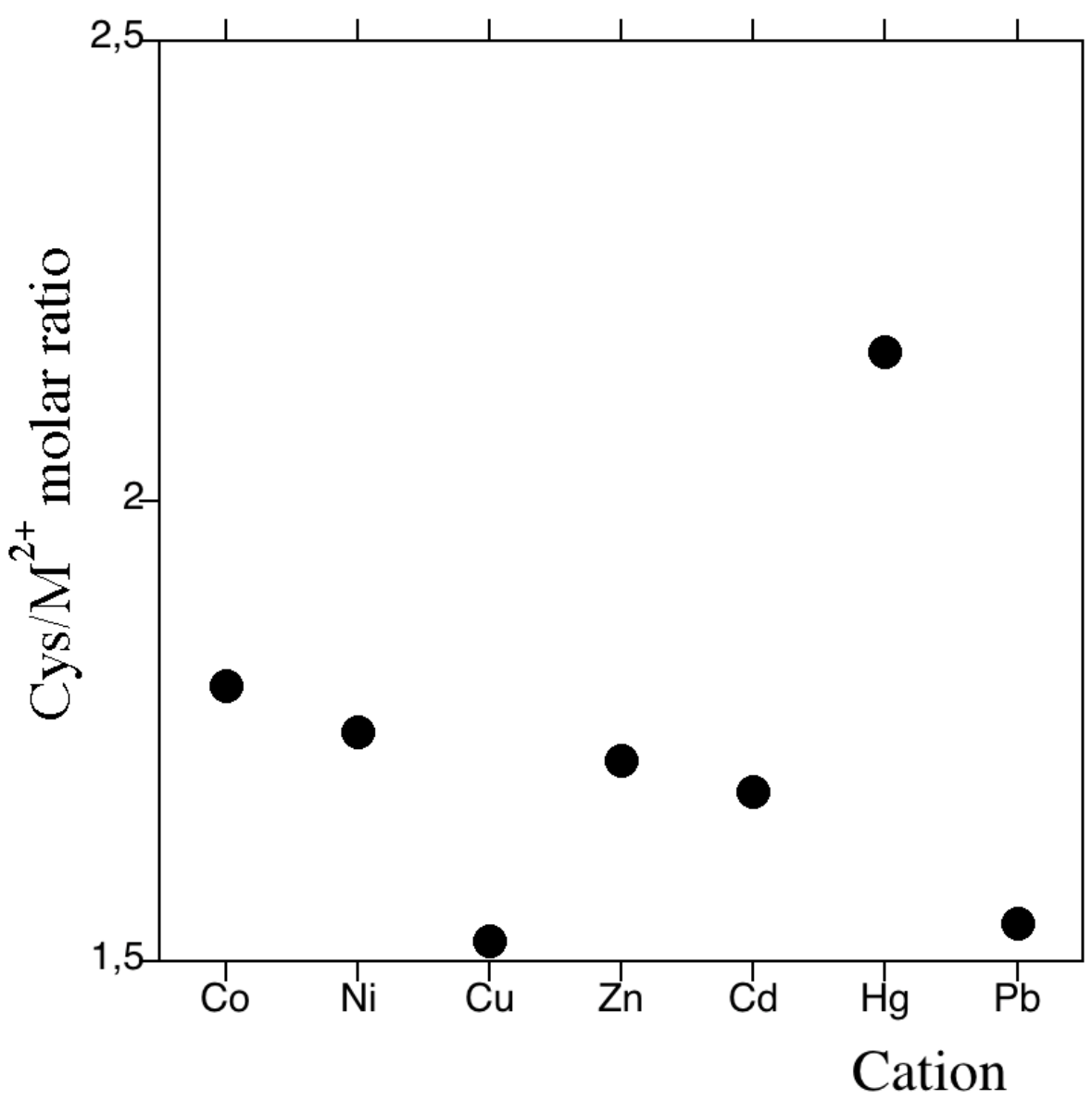

Figure 7: Cysteine/cation molar ratios for the heavy metals-Cys-Mt composites 


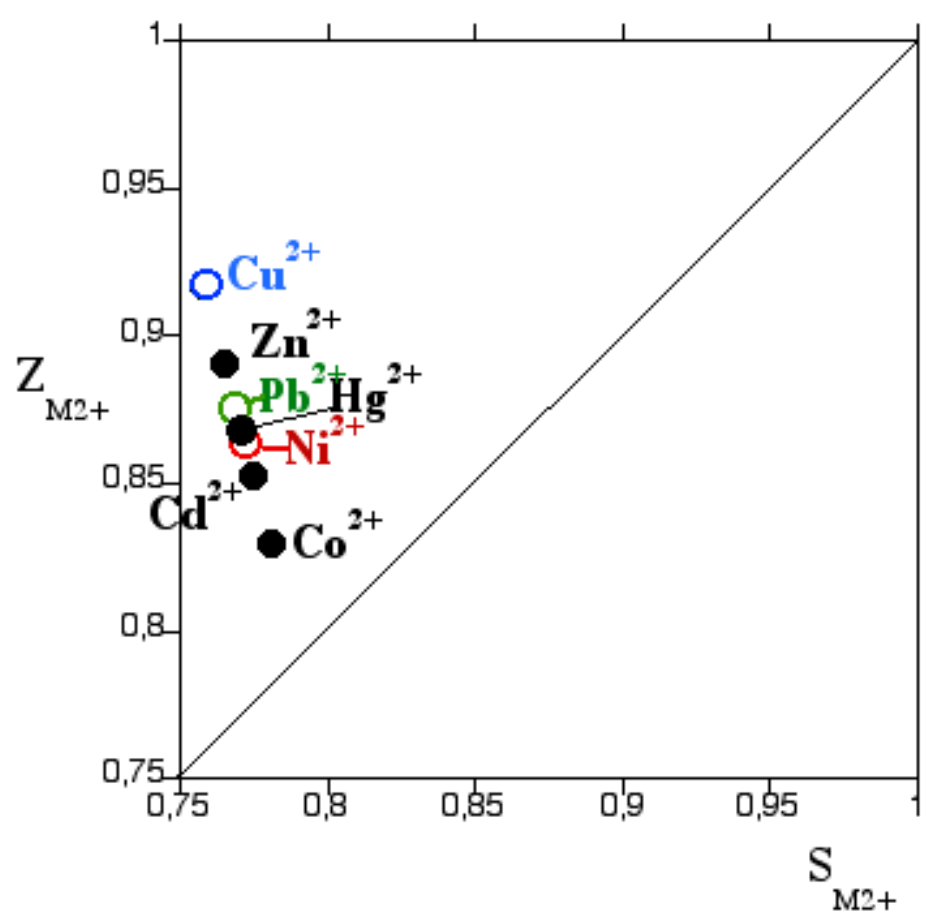

Figure8: Affinity data for the various metal cation adsorbed on cysteine-montmorillonite (i.e., heavy metals-Cys-Mt systems), plotted as a square diagram.

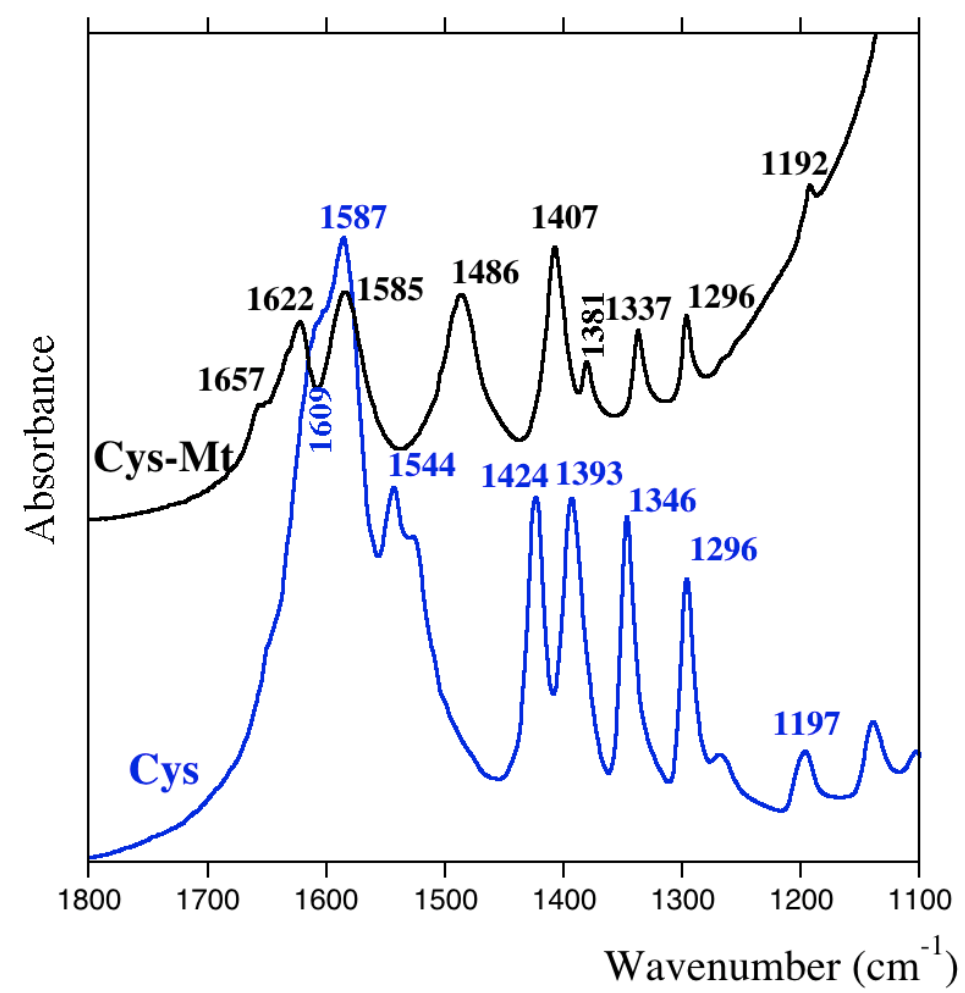

Figure 9: IR spectra of bulk cysteine and of Cys-Mt. 


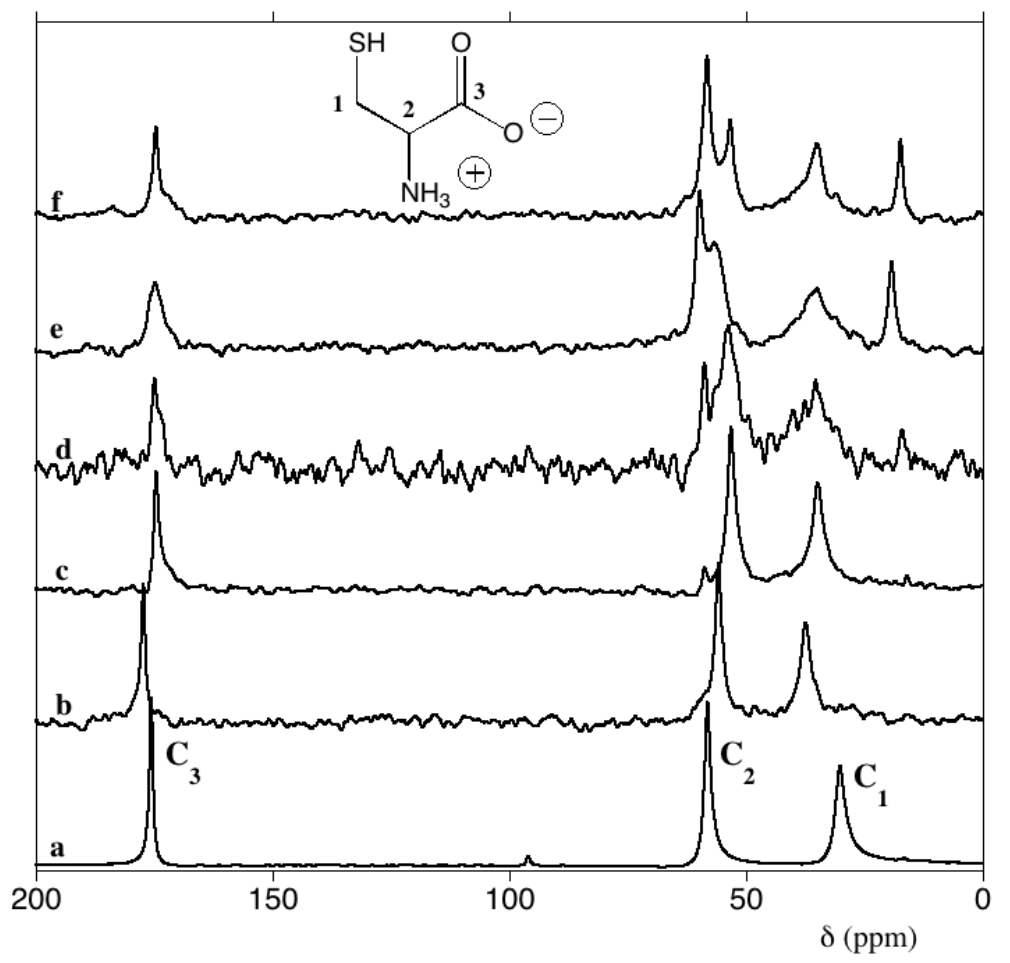

Figure10: ${ }^{13} C M A S-N M R$ spectra of a. bulk cysteine, b. Cys-Mt, c. Zn-Cys-Mt, d. Cd-CysMt, e. Hg-Cys-Mt, f. Pb-Cys-Mt. 


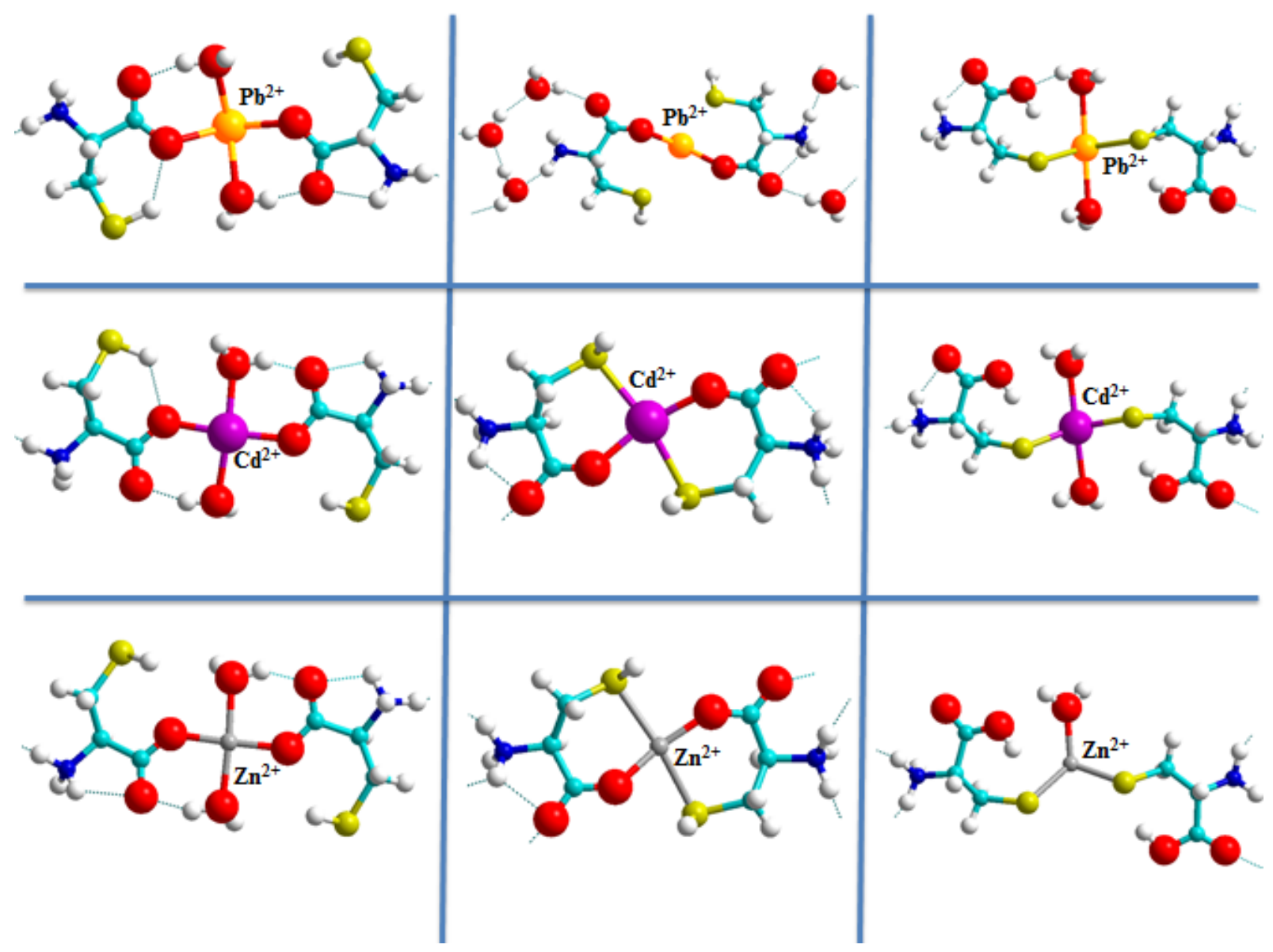

Figure 11 : Coordination sphere of the different studied cations, in the xy plane, perpendicular to the clay interlayer. Only the most stable configuration is shown. Atoms: white $=H$, red $=O$, light blue $=$ carbon, yellow $=S$, blue $=N$. The cations are indicated in the figure and can be orange, grey or green. 


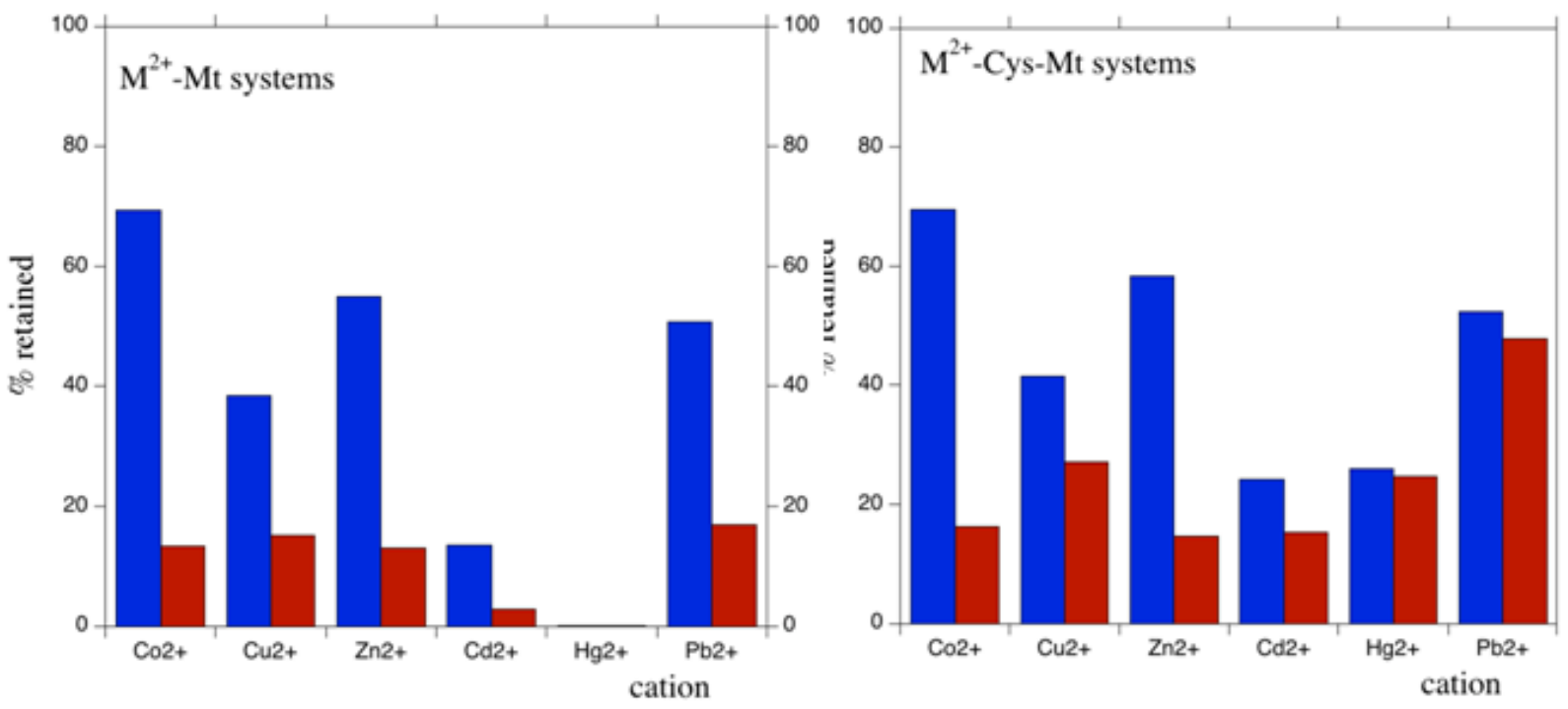

Figure 12: Amount of metal ions after contact with $\mathrm{NaCl}$ solution (0.1 M) (blue) and $\mathrm{SrCl}_{2}$ solution 0.1M (red), in Mt (left) and Cys-Mt composites (right). 